\title{
Atsinaujinančių energijos išteklių naudojimo Lietuvoje patirtis, reikšmė ir siekiai
}

\section{Mantas Marčiukaitis,}

\section{Eugenija Farida Dzenajavičienė,}

Vaclovas Kveselis,

Juozas Savickas,

Eugenijus Perednis,

Aurimas Lisauskas,

Antanas Markevičius,

Kazys Marcinauskas,

Giedrius Gecevičius

Regina Erlickytė-Marčiukaitienė

Lietuvos energetikos institutas,

Atsinaujinančiu ištekliu ir efektyvios energetikos

laboratorija, Breslaujos g. 3, LT-44403 Kaunas

El.paštas Mantas.Marciukaitis@lei.lt
Atsinaujinantys energijos ištekliai (AEI), jų efektyvus naudojimas ir plètra yra vienas iš esminių darnios nacionalinès energetikos strategijos tikslų, kurių igyvendinimas mažina priklausomumą nuo iškastinio kuro importo, didina energijos tiekimo patikimumą ir mažina šiltnamio reiškinị sukeliančių dujų emisiją ị atmosferą. Šių išteklių naudojimas gali mažinti energijos gamybos sąnaudas, gerina gyvenamosios aplinkos kokybę, sukuria darbo vietas, taip pat didina užimtumą regionuose ir mažina socialinę atskirtị. Straipsnyje pateikta AEI rūšių naudojimo Lietuvoje apžvalga, šio energetikos sektoriaus būklè, darnumo aspektai - ekonominiai, aplinkosauginiai ir socialiniai, apsvarstytos ateities plètros kryptys bei perspektyvos.

Raktažodžiai: atsinaujinantys energijos ištekliai, klimato kaitos prevencija, energijos tiekimo patikimumas, ekonominè ir socialinė nauda

\section{IVADAS}

Pasauliniu mastu darnios energetikos plètrai itin svarbūs trys pagrindiniai aspektai: energijos prieinamumas, efektyvus energijos naudojimas ir iškastinio kuro pakeitimas atsinaujinančiais energijos ištekliais. Pastarieji du aspektai ne mažiau svarbūs ir Lietuvai. Taigi atsinaujinančių energijos išteklių (AEI) naudojimas yra vienas pagrindinių darnios energetikos plètros aspektų.

Europos komisija išsikèle klimato ir energetikos sričių tikslus, kuriuos privalu pasiekti iki 2020 m. [1]:

- Europos Sajungoje (ES) sumažinti šiltnamio reiškinị sukeliančiu dujų kiekį bent $20 \%$, palyginti su 1990 m. lygiu;
- AEI dalis $2020 \mathrm{~m}$. turi sudaryti bent $20 \%$ bendro galutinio ES energijos naudojimo;

- efektyviau naudoti energiją ir pasiekti, kad pirminès energijos būtų sunaudojama $20 \%$ mažiau, palyginti su numatomu lygiu.

ES iki $2020 \mathrm{~m}$. ketina sumažinti išmetamą teršalų kiekị ne $20 \%$, o net $30 \%$, jei kitos ekonomiškai stipriausios šalys ịsipareigotų sąžiningai prisidèti prie visuotinių pastangų. ES vadovai $2014 \mathrm{~m}$. spalị susitarè [2] dèl naujų $2030 \mathrm{~m}$. klimato ir energetikos tikslų: išmetamą šiltnamio reiškini sukeliančių dujų kieki sumažinti $40 \%$, palyginti su 1990 m. lygiu; ne mažiau kaip 27 \% visos sunaudojamos energijos gauti iš atsinaujinančių išteklių; mažiausia $27 \%$ padidinti energijos naudojimo efektyvumą. 
Lietuva, vykdydama savo energetikos strategijos nuostatas ir tarptautinius įsipareigojimus, kuria ir tobulina teisinę bazę, kuri skatintų darnią energetikos raidą. Pagrindiniai LR teisès aktai, reglamentuojantys AEI naudojimą ir plètrą, yra [3]:

- LR atsinaujinančių išteklių energetikos ịstatymas;

- LR energetikos įstatymas;

- LR žemès gelmių ǐstatymas;

- LR elektros energetikos ịstatymas;

- LR saugomų teritoriju ístatymas;

- LR planuojamos ùkinès veiklos poveikio aplinkai vertinimo įstatymas;

- Nacionalinè atsinaujinančių energijos išteklių plètros strategija;

- Nacionalinis atsinaujinančių išteklių energijos veiksmų planas;

- Elektros energijos, pagamintos naudojant atsinaujinančius energijos išteklius, kilmès garantijų teikimo taisyklès.

Darni AEI plètra yra svarbi priemoné siekiant mažinti priklausomumą nuo importuojamo kuro. Pastaraisiais metais AEI srityje užsibrěžti strateginiai tikslai leido sparčiai pletoti vietinès energijos gamybos pajégumus ir atsinaujinančių išteklių energetiką Lietuvoje.

\section{ATSINAUJINANČIŲ IŠTEKLIŲ ENERGETIKOS PLĖTROS APŽVALGA}

Pagal Europos Parlamento ir Tarybos direktyvą 2009/28/EB dèl skatinimo naudoti AEI energiją, Lietuva yra ịsipareigojusi iki $2020 \mathrm{~m}$. padidinti
AEI dali bendrame galutiniame šalies energijos naudojime iki $23 \%$, o AEI dalị, palyginti su transporto sektoriaus galutiniu energijos naudojimu, visų rūšių transporte - ne mažiau kaip iki 10 \%. Pagal Lietuvos statistikos departamento paskelbtus duomenis, užsibrèžtą $23 \%$ tikslą Lietuva pasieke jau $2014 \mathrm{~m}$. AEI dalis bendrame šalies energijos balanse viršijo penktadalị ir sudare $23,86 \%$.

$2014 \mathrm{~m}$. AEI dalis elektros energijos sektoriuje sudare $12,6 \%$ (2020 m. planuojama $20 \%$ ), šildymo ir aušinimo sektoriuje - 41,61 \% (2020 m. planuojama $60 \%)$ ir transporto sektoriuje - 4,19\% (2020 m. planuojama $10 \%$ ) [4]. $2016 \mathrm{~m}$. gegužès 31 d. LR energetikos ministerijos [3] duomenimis, Lietuvoje yra instaliuotos 2435 elektrinès, turinčios leidimus gaminti elektros energiją iš AEI. Šių elektrinių bendra suminè įrengtoji galia siekia 674,4 MW:

- 2145 saulès elektrinès (71,5 MW);

- 305 vèjo elektrinès (423,7 MW);

- 10 kietosios biomasès elektrinių (54,96 MW);

- 36 biodujų elektrinès (32,7 MW);

- 98 hidroelektrinès (127,8 MW).

Lietuvos statistikos departamento duomenimis, $2014 \mathrm{~m}$. elektrinèse, naudojančiose AEI, iš viso buvo pagaminta 1,510 TWh elektros energijos. Tai sudare $12,6 \%$ bendro šalyje suvartoto elektros energijos kiekio ir 34,3\% viso $2014 \mathrm{~m}$. šalyje pagaminto elektros energijos kiekio, kuris siekè 4,397 TWh [3].

Statistinè informacija apie atsinaujinančių energijos išteklių naudojimo dinamiką nuo $1990 \mathrm{~m}$. pateikta 1-3 pav. [4].

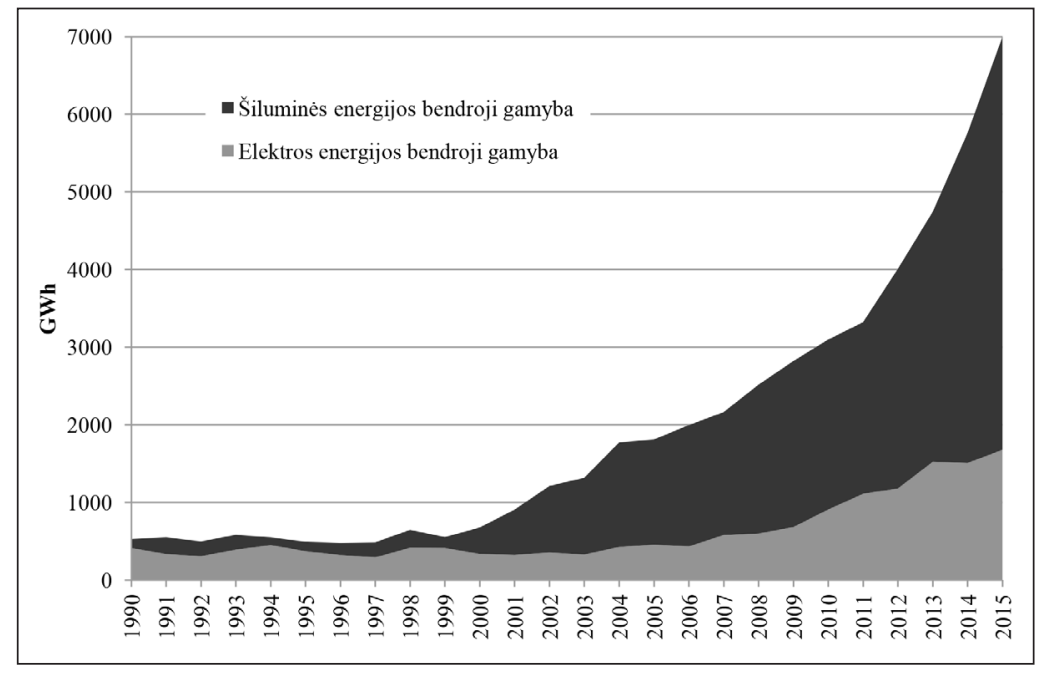

1 pav. Energijos bendrosios gamybos iš atsinaujinančių išteklių dinamika 

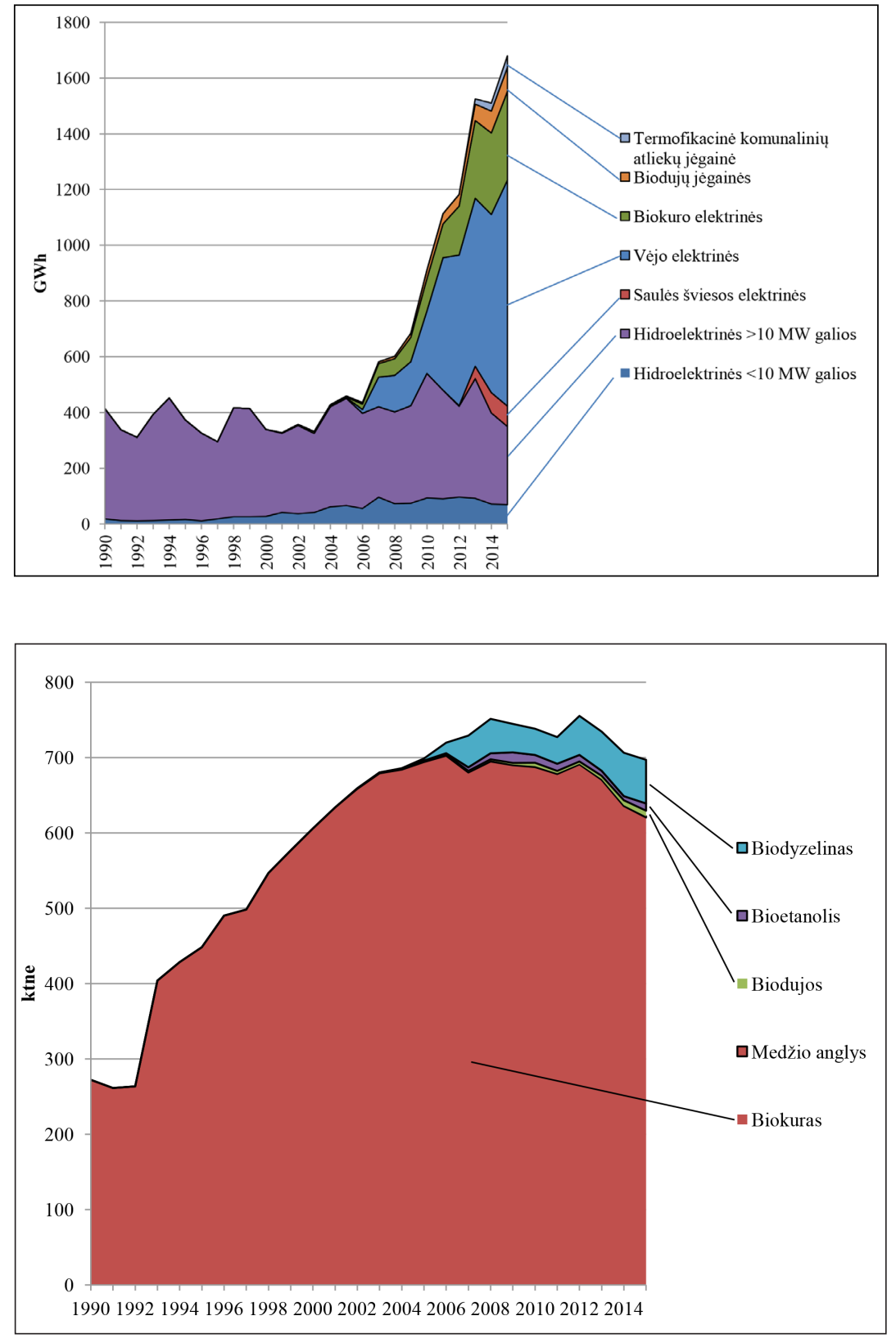

2 pav. Elektros energijos gamybos iš atsinaujinančių energijos išteklių dinamika Lietuvoje
3 pav. Atsinaujinančių energijos išteklių galutinis sunaudojimas Lietuvoje
AEI naudojimas ir plètra yra tiesiogiai susijusi su darnia energetika, todèl vertinant kiekvieną sektorių būtina atlikti ekonominio, aplinkosauginio ir socialinio plètros poveikio vertinimą. Kiekvieno ištekliaus panaudojimas turi būti ekonomiškai efektyvus, prisidèti prie šiltnamio reiškinị sukeliančių dujų emisijos mažinimo, žmogaus ir gamtinès aplinkos gerinimo, o kartu padètų spręsti socialines problemas - kurtų naujas darbo vietas, prisidètų prie regionų plètros ir mažintų gyventojų socialinę atskirtį.

Socialinius aspektus ịvertinti turbūt sunkiausia, nes teikiama finansinè parama nekelia reikalavimo igyvendinti konkrečius socialinius rodik- lius, bet sukurtų darbo vietų skaičius yra labai svarbus AEI plètrai. EurObserv'ER 2012-2014 m. duomenimis, $2014 \mathrm{~m}$. plètojant AEI naudojimą Lietuvoje buvo sukurta 4400 darbo vietų. Biokuro sektoriaus plètra buvo sparčiausia, indèlis šiuo atžvilgiu buvo didžiausias (1 lentelè).

\section{BIOMASĖS ENERGETIKA}

Energijai gaminti iš biomasès gali būti naudojama daug technologijų, pradedant nuo kietos biomasès deginimo pastatų šildymo sistemose iki biodujų gamybos įrenginių ir didelių biomasès dujofikavimo jègainių. Biomasès energetikos 
1 lentelè. Sukurtos darbo vietos diegiant AEI 2012-2014 m. [5]

\begin{tabular}{l|c|c|c|c|c|c|c|c|c|c|c}
\hline & $\begin{array}{c}\text { Iš viso } \\
\text { darbo } \\
\text { vietų }\end{array}$ & $\begin{array}{c}\text { Vejjo } \\
\text { ener- } \\
\text { getika }\end{array}$ & $\begin{array}{c}\text { Kietasis } \\
\text { biokuras }\end{array}$ & $\begin{array}{c}\text { Sauless } \\
\text { šviesos }\end{array}$ & $\begin{array}{c}\text { Biode- } \\
\text { galai }\end{array}$ & $\begin{array}{c}\text { Šilumos } \\
\text { siurbliai }\end{array}$ & $\begin{array}{c}\text { Bio- } \\
\text { dujos }\end{array}$ & $\begin{array}{c}\text { Mažosios } \\
\text { hidro- } \\
\text { elektrinès }\end{array}$ & $\begin{array}{c}\text { Saulès } \\
\text { šluminè }\end{array}$ & $\begin{array}{c}\text { Atlieku } \\
\text { ener- } \\
\text { getika }\end{array}$ & $\begin{array}{c}\text { Geoterminè } \\
\text { energetika }\end{array}$ \\
\hline 2012 & 4715 & 400 & 2975 & 100 & 840 & $<50$ & $<50$ & 150 & $<50$ & n.a & $<100 \mathrm{i}$ \\
\hline 2013 & 5250 & 400 & 3100 & 700 & 800 & 100 & $<50$ & 150 & $<50$ & $<50$ & $<100$ \\
\hline 2014 & 4400 & 100 & 3350 & 150 & 300 & 100 & 150 & $<50$ & $<50$ & $<50$ & $<100$ \\
\hline
\end{tabular}

reikšmė tolydžiai auga didẻjant susirūpinimui dèl klimato kaitą skatinančių emisijų $\mathfrak{i}$ atmosferą. Biomasès naudojimas šilumai gaminti jau dabar yra ekonomiškai pagrịstas, tačiau vis dar reikia priemonių, skatinančių naudoti biomasę gaminant elektrą. Toks skatinimas pagrịstas aplinkosaugos, energijos tiekimo patikimumo ir socialine nauda.

Iš biomasès gaminamas biokuras skirstomas $\mathfrak{i}$ kietąji biokurą, biodujas ir biodegalus.

\section{Kietasis biokuras}

Plètros istorija Lietuvoje ir esama situacija. Kietasis biokuras - iš biomasès pagamintas kietasis kuras, naudojamas energijai gaminti. Ši kuro rūšis gaminama iš miško kirtimo ir tvarkymo, medienos apdorojimo atliekų, specialiai auginamų augalų (medžių ir žolių), miestų, parkų, pakelių tvarkymo, komunalinių ir augalininkystès atliekų.

Alternatyvių energijos išteklių, ịskaitant kietojo biokuro, tyrimus Atsinaujinančių išteklių ir efektyvios energetikos laboratorijos darbuotojai pradejjo nuo Nepriklausomybès atkūrimo ir prasidejusios energetinès blokados - formavo sąvokas, analizavo technologines galimybes, kartu su Lietuvos bei užsienio partneriais dalyvavo vertinant šio ištekliaus techninị ir ekonomini potencialą. Drauge su miškų ir žemès ūkio specialistais kūrè metodikas tokiam potencialui vertinti, vieni pirmųju ịvedè darnios plètros biokuro gamyboje sąvokas, formavo pagrindinius vertinimo kriterijus ir rodiklius, kurių pagrindu atliko kietojo biokuro naudojimo ekonominio veiksmingumo, aplinkosauginès bei socialinès naudos vertinimus. Laboratorijos darbuotojai, bendradarbiaudami su šilumos tiekejais ir biokuro gamintojais, prisidejjo prie šio sektoriaus plètros šilumos ūkyje, paramos priemonių pagrindimo ir veiksmingumo ịvertinimo. Lygiagrečiai atski- ruose projektuose buvo vertinamas ir kai kurios netradicinių kuro rūšių tinkamumas bei potencialas, formuojama centralizuoto šilumos tiekimo sistemų efektyvumo didinimo ir perèjimo prie kietojo biokuro strategija.

Apie $80 \%$ individualių namų šiuo metu šilumai gaminti naudoja biokurą. Tai daugiausia malkos, bet deginama ir dalis medienos bei žemès ūkio produkcijos atliekų, granulès ir briketai. Daugeliu atvejų biokuro katilai pakeitè sovietmečiu populiarų skystąji krosnių kurą. Kietąji biokurą taip pat naudoja individualios katilinès, šildančios kaimo ir mažų miestelių mokyklas, darželius, administracinius pastatus, nedidelius daugiabučius gyvenamuosius namus, kur biokuras pakeitè skysto kuro ir anglių katilus.

Lietuvos biomasès energetikos asociacijos „Litbioma“ duomenimis, biokurui gaminti tinkamos biomasès metini potencialą sudaro: malkinè mediena $\left(0,505 \mathrm{mln}\right.$. tne $\left.\mathrm{e}^{*}\right)$, medžio pramonès atliekos $(0,28 \mathrm{mln}$. tne $)$, miško kirtimo atliekos $(0,185 \mathrm{mln}$. tne), želdynų, sodų, pakelių, pagriovių tvarkymo atliekos $(0,16 \mathrm{mln}$. tne), kelmai $(\sim 0,1 \mathrm{mln}$. tne), energetiniai augalai $(\sim 0,014 \mathrm{mln}$. tne $)$, šiaudai $(0,81 \mathrm{mln}$. tne $)$ ir komunalinès atliekos $(0,09 \mathrm{mln}$. tne). Tai sudaro apie $\sim 2 \mathrm{mln}$. tne arba $\sim 24 \mathrm{TWh}[6]$.

Lietuvos mišku statistikos $2014 \mathrm{~m}$. duomenimis, galutinis malkų ir medienos atliekų naudojimas kuro ir energijos gamybai buvo 1078,7 ktne, iš kurių energetikos imonès sunaudojo 446 ktne, pramonè - 79,2 ktne, statybos sektorius - 2,35 ktne, žemès ūkis - apie 10,4 ktne, paslaugų sektorius - 32,4 ir namų ùkiai - 509 ktne. $2014 \mathrm{~m}$. Lietuvos urèdijos pardavè 104,3 ktne malkinès medienos, iš kurių 44,5 ktne eksportuota ir 7,62 ktne importuota [7]. Kapotinès medienos (skiedros) gamyba miško statistikoje nèra išskirta.

\footnotetext{
* the - tona naftos ekvivalento - energijos matavimo vienetas, lygus 11,63 MWh, arba 41,84 GJ.
} 
Didžiausi kietojo biokuro vartotojai yra namų ūkiai ir centralizuoto šilumos tiekimo (CŠT) įmonès. Pramoninè biokuro naudojimo plètra Lietuvoje prasidejo $1994 \mathrm{~m}$., kai buvo irengtos pirmosios katilinès, kūrenamos kapotine medienos skiedra ar pjuvenomis. Šios veiklos pradininkais reikètų laikyti Biržų ir Molètų CŠT, kur pirmuoju atveju su švedų, o antruoju su danų pagalba buvo įrengtos pirmosios biokurą deginančios katilinès. Galutinai ši pramonès šaka ịsitvirtino $1999 \mathrm{~m}$.

Tolesnei biokuro naudojimo CŠT sistemose plètrai daugiausia ittakos turèjo padidèję aplinkosauginiai reikalavimai [8], išaugusios gamtinių dujų ir mazuto kainos, šilumos rinkos atverimas nepriklausomiems gamintojams [9], biokuro gamybos sektoriaus plètra bei biokuro biržos sukūrimas. Svarbus indèlis AEI srityje teko dirbantiesiems mokslininkams ir biokuro įrangos gamintojams, jos naudotojų lobistinei veiklai.

Valstybinès kainų ir energetikos kontrolès komisijos duomenimis [10], $2016 \mathrm{~m}$. I ketv. šilumos gamybos rinkoje veikè 40 nepriklausomų šilumos gamintojų: 23 reguliuojami ir 17 nereguliuojamų. 2016 m. I ketv. nepriklausomi šilumos gamintojai pardave 1 106,5 tūkst. MWh šilumos, kurios $75,3 \%$ pagaminta naudojant atsinaujinančius energijos išteklius.

Lygiagrečiai su biokuro gamybos sektoriumi plètèsi ir pirmoji Europoje biokuro birža, veikianti kaip internetinè prekybos aikštelè. Čia anonimiškai susitikę biokuro pardavejjai ir pirkejai gali greitai ir paprastai sudaryti sandorius. Taip skatinama konkurencija biokuro rinkoje, užtikrinamos sąlygos susiformuoti skaidriai, objektyviai ir ekonomiškai pagrịstai biokuro kainai [11]. Vidutinè svertinè biokuro kaina per $2015 \mathrm{~m}$. šildymo sezoną sumažèjo apie $13 \%$, palyginti su 2014 m., ir sieke 147,78 €/tne. Kartu auga ir prekybos biokuru apimtys - biokuro pirkejjai vis dažniau renkasi ne dvišalius sandorius, bet prekybą biržoje [12].

Lietuvos šilumos tiekejjų asociacijos duomenimis, $2014 \mathrm{~m}$. šilumos sektoriaus katilinèse instaliuota biokuro katilų galia sieke $1181 \mathrm{MW}$, iš kurių $749 \mathrm{MW}$ - šilumos tiekimo įmonèse ir 432 MW - nepriklausomų gamintojų šilumos šaltiniuose. Iki $2020 \mathrm{~m}$. planuojama pasiekti $2548 \mathrm{MW}$ suminę biokuro įrenginių galią.
Bendrame šilumai gaminti sunaudojamo kuro balanse $2014 \mathrm{~m}$. biokuro dalis viršijo $45 \%$, o igyvendinus Vilniaus ir Kauno biokogeneracijos projektus $2020 \mathrm{~m}$. ši dalis turètų siekti net $80 \%$. Šiuo metu veikia 8 biokogeneracinès jègainès, su instaliuota 132,2 $\mathrm{MW}_{\breve{s}}$ šilumos ir 40,26 $\mathrm{MW}_{\mathrm{e}}$ elektros galia [13].

Augant šilumos generavimo iš biokuro galioms, auga ir tokio biokuro paklausa. Praktiškai pusè reikalingo kuro yra importuojama iš kaimyninių valstybių. Siekiant geriau išnaudoti vietinius išteklius, diversifikuoti kuro šaltinius ir užtikrinti tiekimo patikimumą, kilo poreikis ìvertinti kitus kurui tinkamos biomasès išteklius. Vienas jų yra šiaudai, kurie tampa konkurencingu kuru katilinèse. Šiuo metu 4 stambiausiose šiaudų deginimo katilinèse instaliuota galia yra 4,29 MW. Lietuvoje biokurui ruošti per metus surenkama apie 130-140 tūkst. t šiaudų, kurių didžioji dalis panaudojama granulems gaminti. Lietuvoje $2012 \mathrm{~m}$. veikè per 20 šiaudu granulių gamintojų [6]. Beveik visos šalyje pagamintos šiaudų granulès yra eksportuojamos ì užsieni, nes Lietuvoje šis kuras per brangus. Nustatyta, kad dabar Lietuvoje eksploatuojami medžio pjuvenų granulių katilai nèra tinkami efektyviai deginti šiaudų granules. Dabartinè situacija ipareigoja konstruoti ne pramonei skirtu šiaudų granules deginančius katilus ir užtikrinti, kad visi šiaudų granulių gamintojai tiektų savo produkciją, atitinkančią Lietuvoje galiojantị standartą LST EN 14961-6:2012. Kadangi šiaudų naudojimo didinimas reikalauja papildomų investicijų, Vyriausybei reikètų apsvarstyti ūkininkų ir šio kuro gamintojų skatinimo mechanizmus.

Klaipèdoje $2013 \mathrm{~m}$. pradejjo veikti pirmoji biokurą ir komunalines atliekas deginanti kogeneracinè jègainè. Jègainès šilumos galia - $50 \mathrm{MW}$, elektros - 20 MW. Imonès duomenimis, $2015 \mathrm{~m}$. iš atsinaujinančių energijos išteklių pagaminta 193,685 GWh šilumos [14]. Dar dvi tokị kurą deginančios kogeneracinès jègainès projektuojamos Kaune ir Vilniuje.

Lietuvoje esama ir netradicinio biokuro deginimo pavyzdžių. Vienas jų - grikių kruopų gamybos ir fasavimo atliekos, kai pritaikius unikalią deginimo technologiją yra deginami grikių lukštai. Ivertintas šio kuro potencialas ir panaudojimo perspektyvos, taip pat atlikta jų efektyvaus 
panaudojimo analizè. Kiti produktai - rapsų išspaudos, naudojamos granulems gaminti; aliejaus pramonès gamybos atliekos - saulègrąžų lukštai, iš kurių gaminamos granulès ir briketai, pastaraisiais šiuo metu prekiaujama rinkoje [15, 16]; vienoje iš Lietuvos katilinių deginami išaižyti spygliuočių kankorèžiai.

Viena iš kietojo biokuro rūšių yra greitai augantys želdiniai: medžiai - gluosniai, tuopos, bei energetinès žolès, iš kurių geriausiai žinomi ir taikytini - nendriniai eraičinai, paprastosios šunažolès ir nendrinis dryžutis [17]. Ši biokuro rūšis kol kas naudojama labai ribotai dèl aukštu gamybos kainų ir nepakankamai ịsisavintų technologiju.

Ekonominiai aspektai. Biokuro gamyba iš medienos ir žemès ūkio atliekų tampa vis svarbesné ūkio šaka, kurioje auga gamybos apimtys, sukuriama pridètinè vertè ir didejja dirbančiųjų skaičius. Didelè dalis pagaminto aukštos kokybès biokuro (granulių, briketų) yra eksportuojama, ir tai gerina šalies užsienio prekybos balansą. Apskaičiuota, kad biokuro (smulkintos medienos) naudojimo šilumai gaminti projektų atsipirkimo laikas be ES paramos yra 6-7 metai, esant gamtinių dujų ir biokuro kainų skirtumui 10,8€/MWh. Mažesnis kuro kainų skirtumas prailgintu atsipirkimo laiką projektams, pradètiems 2012-2014 m. Šiaudų vidutinè kaina 2011-2014 m. padidèjo nuo 153 iki $159 € /$ tne, o šiaudų granulių ( $8 \%$ drègnumo) kaina yra apie 260-320 €/tne. Ekonominiu požiūriu rekomenduojamas maksimalus žaliavos gabenimo atstumas yra iki $60 \mathrm{~km} \mathrm{[6].}$

Ekologiniai aspektai. Taršos integruotos prevencijos ir kontroles (TIPK) direktyva (2010/75/ES) sugriežtino teršalų, išmetamų iš didelių (>50 MW) kurą deginančių irrenginių, maksimalias normas po $2016 \mathrm{~m}$. TIPK direktyvos igyvendinimas ne tik pareikalaus naujų degikliu esamuose katiluose, bet reikès įdiegti ir gana brangias dūmų valymo technologijas mazutą ir gamtines dujas deginančiuose energetikos objektuose. Jeigu CŠT sektoriuje ir toliau išliktų esami šilumos generavimo įrenginiai ir būtų naudojamas tas pats kuras, tai apskaičiuotas bendras investicijų poreikis, užtikrinant TIPK direktyvos reikalavimus, yra vertinamas apie $573 \mathrm{mln}$. € [18]. Dideliuose katiluose patenkinti aplinkosaugos reikalavimus yra papras- čiau, nes jau dabar tokie įrenginiai turi kietujų dalelių filtrus, o išmetami dūmai „praplaunami“ kondensaciniuose ekonomaizeriuose. Pavyzdžiui, UAB „Fortum Klaipèda“ jègainèje teršalų koncentracija išeinančiuose dūmuose yra keletą ar net keliasdešimt kartų mažesnè, nei numatyta ES ir Lietuvos norminiuose dokumentuose.

2007-2013 m. ịdiegti biomasès deginimo ịrenginiai Lietuvos šilumos ūkyje kasmet sumažins $\mathrm{CO}_{2}$ išmetimą í aplinką iki $0,78 \mathrm{mln}$. t, gamtinių dujų sunaudojimas sumažès 3500 GWh. Vertinant gamtinių dujų ir biomasès kainų skirtumą $2015 \mathrm{~m}$., finansinis sutaupymas kiekvienais metais siektų iki 38,3 mln. €, tačiau dèl itin griežtų aplinkosauginių reikalavimų įmonèms, gerokai padidinusioms naudojamo biokuro kiekius, kilo rimta problema - pelenų sutvarkymas. Šiuo metu katilinèse susikaupè dideli pelenų kiekiai, kurių dèl aplinkosauginių reikalavimų negalima vežti î nepavojingų atliekų sąvartynus [19].

Socialiniai aspektai. Naujų darbo vietų sukūrimas vertintinas kaip socialinè nauda. Per 10 metu (2004-2014) dèl biokuro gamybos ir naudojimo plètros darbo rinkoje sukurta 6,5 tūkstančiai darbo vietų. Igyvendinus visus planuojamus biokuro energetikos projektus, iki $2020 \mathrm{~m}$. šiame sektoriuje darbo vietų skaičius išaugs iki 10 tūkst. [6]. Vidutinè su ES paramos priemonių igyvendinimu susijusios darbo vietos sukūrimo kaina yra 30-35 tūkst. $€$, o investuojant ị infrastruktūrą siekè apie 33,6 tūkst. $€$. Mažiausia kainavo darbo vieta investuojant $\mathfrak{i}$ žmogiškąji kapitalą - vidutiniškai apie 30 tūkst. €. Investicijos ị infrastruktūrą pasižymëjo stipresniu multiplikavimo efektu, todèl vidutinè vienos ilgalaikès darbo vietos kaina čia buvo truputi mažesnè, palyginti su kitais lèšų paskirstymo tipais [20].

Ateities plètros tikslai ir perspektyvos. Biokuro rinka pastaraisiais metais sparčiai augo didejjant šio kuro paklausai ne tik Lietuvos, bet ir užsienio rinkose. Šio energijos ištekliaus gamybos pletrą pirmiausia gali riboti šalyje esantis biomasès potencialas, kuris šiuo metu rengiamos Nacionalinès energetikos strategijos projekte ivertintas iki $8 \mathrm{mln} . \mathrm{m}^{3}$ (1 $\left.568 \mathrm{ktne}\right)$ per metus. Tolesne tarptautines prekybos plètra šiame sektoriuje tikètina didins konkurenciją ir gali sukurti nepalankias ekonomines sąlygas Lietuvos biokuro gamintojams. Biokuro naudojimo plètra tokiose didelèse šalyse kaip Vokietija, Jungtinė Karalystė, Skandinavijos 
valstybès jau dabar daro spaudimą Lietuvos biokuro vartotojams dèl aukštesnių supirkimo kainų.

Nacionalinès energetikos strategijos projekte kietajam biokurui numatomas svarbus vaidmuo igyvendinant energetikos ir aplinkosaugos tikslus, ypač šilumos gamyboje. Biokuro naudojimas iki $2020 \mathrm{~m}$. CŠT turètų pasiekti 372,2 ktne kietojo biokuro. Bendras kietojo biokuro poreikis šilumos energijos gamybai sieks 1 104,8 ktne arba $67 \%$ jo bendro prognozuojamo potencialo [21]. Ivertinant tai, kad medienos biomasès potencialas yra ribotas, biokuro gamybos plètra turètų būti orientuota ir ị kitos biomasès, visų pirma žemès ùkio ir komunalinių atliekų, naudojimą.

Neigiamos biokuro gamybos ir naudojimo pasekmès siejamos su atmosferos tarša jo gamybos ir transportavimo metu bei naudojimu individualių namų šildymo sistemose, neturinčiose dūmų valymo įtaisų. Šiuo metu taip pat dar nèra visiškai išspręstos ir pelenų tvarkymo problemos.

\section{Biodujos}

Plètros istorija Lietuvoje ir esama situacija. Biodujų gamybos iš organinių atliekų galimybių tyrimai Lietuvos energetikos institute buvo pradèti susidarius šalyje atitinkamai ekonominei situacijai ir dèl kelių konkrečių priežasčių: 1) siekiant iqvertinti energijos gamybos iš atsinaujinančiu energijos išteklių galimybes; 2) klimato kaitą skatinančių dujų emisijos mažinimo galimybių tyrimo; 3) paviršinio ir gruntinio vandens išteklių teršimo skystomis pramonès gamybinèmis nuotekomis mažinimo galimybių ịvertinimo; 4) socialinių bei ekonominių problemų sprendimų paieškos.

Laboratorijoje daugeli metų buvo atliekami tiriamieji darbai biodujų gamybos bei jų racionalaus panaudojimo efektyvumo didinimo temomis, pateiktos atitinkamos išvados ir rekomendacijos. Šių darbų rezultatai paskatino šalies verslininkus plačiau diegti anaerobinio organinių atliekų apdorojimo technologijas praktikoje. Be to, svarbus aspektas šioje srityje buvo Lietuvos ịstojimas ị Europos Sajungą, kai tapo privalu griežčiau laikytis aplinkos apsaugos reikalavimų, nustatytų atitinkamomis ES ir Tarybos direktyvomis.

Ideja realiai gaminti biodujas iš organinių atliekų mūsų šalyje pirmą kartą kilo apie 19811983 m. Šių technologijų efektyvumą praktiškai išbandyti buvo planuojama viename iš 31 tuo metu veikusių kiaulininkystès kompleksų, apdorojant jame susidarančio skysto méšlo kiekius. Latvijoje toks projektas tuo metu jau veike kiaulininkystès komplekse prie Ogrès. Eksperimentas parodè, kad technologiniu požiūriu anaerobinis organinių atliekų apdorojimas yra įmanomas, biodujos išsiskiria ir gerai dega komplekso katilinejje, o méšlas mineralizuojasi daug geriau nei laikant mèšlidèje ar kūdroje.

Anaerobiškai apdorojant skystą méšlą, kaip ir kitas organines atliekas, bioduju gamybos technologija vertinama kaip efektyvi, galinti išspręsti daugybę uždavinių ir problemų. Iki Nepriklausomybès atgavimo Lietuvoje veikè 33 kiaulininkystès kompleksai, kuriuose buvo įrengtos hidraulinès méšlo šalinimo sistemos. Kiekvieno komplekso potenciali organinių atliekų tarša prilygintina 3-5 mln. gyventojų miesto nuoteku taršai, todèl buvo planuojama prie šių kompleksų pradèti anaerobinio organinių atliekų apdorojimo technologijų diegimą.

Praktiškai igyvendinti šią idejją kartu su užsienio specialistais Lietuvos mokslininkai pabandè kaip alternatyvą tada pradètoms naudoti skystųjų organinių atliekų valymo technologijoms, kurios buvo itin brangios ir nepakankamai efektyvios. Tačiau daug pažangesnes anaerobinio organinių atliekų apdorojimo technologijas reikejjo ištirti ir tobulinti. Tyrimų poreikị lèmè didelę žalą aplinkai darančių kiaulininkystès kompleksų sparti plètra bei praktiškai beveik nevalomos miestų ir miestelių nuotekos.

Padedant Danijos atsinaujinančių energijos šaltinių centro specialistams ir gavus Danijos Vyriausybès finansavimą buvo pastatyta pirmoji Lietuvoje demonstracinè biodujų jègainè Kauno rajone. Šio projekto igyvendinime aktyviai dalyvavo ir laboratorijos specialistai. Jègainès bioreaktorių tūris sudare $900 \mathrm{~m}^{3}$. Siekiant ištirti biodujų išeigos priklausomumą nuo įvairių priedų, buvo irengti trys horizontalūs bioreaktoriai. Energetikos sektorių sudare du kogeneraciniai blokai (bendra elektrinè galia $110 \mathrm{~kW}$ ) ir du vandens šildymo katilai. Laboratorijos iniciatyva biojègaineje buvo įrengtas eksperimentinių tyrimų centras, kuriame atliekami biodujų kokybès tyrimai, kurių pagrindu buvo rengiami straipsniai, skaitomi pranešimai šalies ir užsienio konferencijose. Pagrindinis vykdomų darbų tikslas - parengti tobulesnes biodujų 
gamybos ir panaudojimo technologijas, sumažinti investicijas naujoms biodujų jegainèms statyti, pagerinti jų energetinį ir ekonominį efektyvumą. Tirtas biodujoms gaminti naudotinų organinių medžiagų energetinis potencialas, techninès ir technologinès jų panaudojimo galimybès, energetinis, ekonominis ir gamtosauginis jų perdirbimo efektyvumas. Nagrinëjamos biodujų gamybos iš žaliosios augalų masès galimybès, atliekamas biodujų surinkimo ir jų utilizavimo sistemų irrengimo pagrindimas stambiausiems Lietuvos sąvartynams.

Šiuo metu Lietuvoje veikia 28 biodujų ir 8 sąvartynų dujų jègainès, kuriose instaliuota 9,481 MW šilumine ir 32,7 MW elektrinè galia [22].

Vienu iš šiuo metu pavyzdinių projektų laikytina Pasvalyje veikianti biodujų ir biodegalu gamybos jègaine „Kurana“, kurioje per metus pagaminama apie $25 \mathrm{mln} . \mathrm{Nm}^{3}$ biodujų iš bioetanolio gamybos atliekų ir kitų organinių priedų. Pagamintos biodujos deginamos termofikacinès elektrinès kogeneratoriuose ir garo katiluose. Bendras elektros ir šilumos galingumas siekia 16,5 MW. Dalis pagamintos šiluminès bei elektros energijos sunaudojama savo poreikiams technologiniame procese, pertekline dalis elektros energijos parduodama elektros tinklams, o šilumos energija - $A B$ „Panevėžio energija“ Pasvalio rajono katilinei.

Viena biodujų jegainè, neutralizuojanti kiaulininkystès kompleksų kvapus, įrengta šalia Kelmès rajone esančio „Idavang“ kiaulininkystės komplekso „Sajas“, kita - prie komplekso „Pasodèlë“, esančio Panevėžio rajone. Šiose biodujų jègainèse apdorotas kiaulininkystès kompleksuose susidarantis skystas méšlas tampa kokybiškomis trąšomis, o jo apdorojimo metu susidarančios biodujos sunaudojamos elektrai ir šiluminei energijai gaminti.

Daug dèmesio skiriama sąvartynų dujų panaudojimui. Kai Lietuvoje vietoj didelio skaičiaus išsklaidytų sąvartynų buvo sukurta 10 regioninių atliekų tvarkymo centrų, atsirado galimybių didžiausiuose jų statyti ir sąvartynų dujomis veikiančias jègaines, gaminančias ir fiksuotu tarifu parduodančias elektros energiją nacionaliniam operatoriui. Šiuo metu yra 8 tokios jègainès, kurių bendra instaliuota galia $8,57 \mathrm{MW}_{\mathrm{el}} 2015 \mathrm{~m}$. jos pagamino 24,3 GWh elektros energijos. Išskirtiniu atveju galima laikyti Lapių sąvartyno projektą, kur dujos nutiestu vamzdynu tiekiamos i Domeikavos katilinę ir ten pakeičia dalị gamtinių dujų šilumos gamyboje.
Biodujų gamyba šalyje yra remiama ir skatinama. Pagrindinè bioduju gamybos ir naudojimo Lietuvoje skatinimo priemone yra fiksuotas elektros energijos, pagamintos iš biodujų ir sąvartynų dujų, supirkimo tarifas. Taip pat skirta parama ūkininkams žemès ūkio ministro $2007 \mathrm{~m}$. gegužès 5 d. ìsakymu Nr. 3D-223 „Dèl paramos už energetinius augalus, skirtus biokuro gamybai, administravimo ir kontrolès taisyklių patvirtinimo", kuriame numatoma parama ir jos dydis ūkininkams, auginantiems augalus biodegalams gaminti.

Pagal Lietuvoje veikiančių bei veikusių biodujų jègainių veiklos rezultatus ir užsienio šaltinius [23-25] nustatyta, kad taikant anaerobinio organinių atliekų apdorojimo technologijas yra sprendžiamos aplinkosaugines, energetinès, socialines bei agrokultürinés problemos.

Aplinkosauginiu atžvilgiu biodujų gamybos ir naudojimo privalumas yra tai, kad anaerobinèmis sąlygomis bioreaktoriuose efektyviai (iki 40-60\%) suskaidomos organinès medžiagos, taip sumažinamas apdorotų nuotekų neigiamas poveikis aplinkai.

Energetinio efektyvumo esmę sudaro tai, kad pagamintos biodujos vertinamos kaip vietiniai, atsinaujinantys energijos ištekliai, kurie, atsižvelgiant $\mathfrak{i}$ konkrečias sąlygas, yra naudojami kaip kuras katilinèje ar stacionariose kogeneracinèse jègainèse šiluminei ir elektros energijai gaminti.

Socialines problemos sprendimas pasireiškia kuriant papildomas darbo vietas (1 lentelè), nes plečiant gamybos veiklos sritis ir darbų apimtis reikia naujų, specifinių specialybių darbuotojų.

Agrokultūrinis efektyvumas biodujų gamybos pramonèje pasiekiamas organizavus organinių trąšų gamybą. Apdorojant atliekas bioreaktoriuje dèl technologinio proceso ypatumų pageréja fermentacijos proceso atliekų (substrato) savybès.

Ateities plètros tikslai ir perspektyvos. Pastaraisiais metais nagrinejjamos biodujų gamybos galimybès iš ịvairesnių organinių medžiagų (šiaudų, žolès, karklų ir pan.) [26]. Tačiau ši kryptis reikalauja atskiro sprendimo, nes prioritetas bus teikiamas energetikos, o ne aplinkosaugos sričiai, kai svarbiausia tampa biodujų kaip energijos išteklių gamyba. Šiuo atveju reikia îvertinti papildomas išlaidas žaliavoms auginti, paruošti, po to apdorotam (degazuotam) substratui sutvarkyti. Šios išlaidos papildomai padidins gaminamos 
energijos, kurios gamyba ir taip visose šalyse yra dotuojama, savikainą.

Smulkiuose ir vidutiniuose ūkiuose susidarančių skystos organinès kilmès atliekų neigiamam poveikiui aplinkai sumažinti rekomenduojama įrengti mažo tūrio bioreaktorius, parenkamus atsižvelgiant ị turimų gyvulių rūš ir skaičių. Tokiuose ūkiuose susidarančios organinès atliekos priskiriamos išsklaidytos aplinkos taršos šaltiniams, kurios užteršia didelius žemės plotus ir gali užteršti nitratais bei sunkiaisiais metalais paviršinio bei gruntinio vandens išteklius. Visais atvejais rekomenduojama ịvertinti galimybę steigti kolektyvines, didesnio tūrio biodujų jègaines, $\mathfrak{i}$ kurias srutos suvežamos specialiu transportu, o ekologiškų trąšų gamybos organizavimas prie jų, sukurdamas papildomas darbo vietas, dar padidina organinių atliekų panaudojimo efektyvumą.

Menkas šilumos sunaudojimas savo poreikiams gaminant elektros energiją iš biodujų lèmè ìstatymo pakeitimą dèl trečiosios pusès prisijungimo prie eksploatuojamų gamtinių dujų tinklų [27]. Tai suteiké biodujų gamintojams dar vieną perspektyvią galimybę - tiekti biodujas ị gamtinių dujų tinklus (ten, kur tokių tinklų esama), tačiau tiekiamų biodujų kokybė privalo atitikti gamtinių dujų kokybę, o biodujų valymo technologijos yra brangios.

\section{Biodegalai}

Plètros istorija Lietuvoje ir esama situacija. Alternatyvių degalų sąvoka pradèta plačiau vartoti Lietuvai atgavus nepriklausomybę, kai sugriuvus Lietuvoje didžiosioms šalies pramonès įmonèms didžiausia aplinkos tarša teko sparčiai besiplečiančiam transporto sektoriui. Lietuvoje transporto priemonès lemia apie $70 \%$ visos atmosferos taršos, todèl buvo svarbu mineralinius degalus pakeisti alternatyviais degalais, pavyzdžiui, biodegalais. Taip intensyviau pradèta ieškoti būdų aplinkos taršai šalies transporte mažinti. Lietuvos Respublikos Vyriausybè patvirtino Biokuro gamybos ir naudojimo skatinimo 2004-2010 m. programą [28], kurioje buvo numatomos priemonès ir atskirų institucijų atsakomybė plečiant biodegalų gamybą ir naudojimą. Mažinti aplinkos teršimą skatino ir ịpareigojo privalomais tapę EK direktyvos ir nutarimai.

Ieškant galimybių îvykdyti ES iškeltus strateginius tikslus - padvigubinti biodegalų dali ES ener- gijos balanse 2010 m. nuo 6 iki $12 \%$, šiam sektoriui buvo skirta daug demesio. Pagaminti iš biomasès biodegalai yra tiesioginis iškastinio kuro pakaitalas transporto priemonèse, juos galima lengvai integruoti i kuro tiekimo sistemas. Tačiau bioetanolis sunkiau skynèsi kelią i rinką, todèl laboratorijos mokslininkams reikejjo realiomis sąlygomis atlikti nemažai eksperimentinių tyrimų, praktiškai naudojant įvairios bioetanolio koncentracijos mišinius. Taip pat buvo atliekami eksperimentiniai bandymai tiriant biodegalu poveikị guminèms variklių detalems, jų sukietejimui, tirpumui, t. y. ilgaamžiškumui [29]. Be to, bioetanolio naudojimą labai ribojo biodegalų išsisluoksniavimo reiškinys, kurị taip pat tyre LEI Atsinaujinančių išteklių ir efektyvios energetikos laboratorijos mokslininkai. Galiausiai buvo pateikti variklių techninių charakteristikų bandymų rezultatai naudojant įvairios koncentracijos $(5 ; 7,5 ; 10 ; 15 ; 20$ ir $30 \%)$ bioetanolio ir benzino mišinius.

Alternatyviems degalams priskiriami:

- bioetanolis, kaip alternatyva benzinui ar jo priedas;

- biodyzelinas, kaip alternatyva dyzelinui ar jo priedas;

- sintetiniai degalai (BtL);

- dujiniai degalai, kuriuos sudaro:

- suskystintos naftos dujos;

- suspaustos gamtinès dujos;

- biodujos;

- biometanas;

- hytanas (biometano ir vandenilio mišinys);

- vandenilis.

Populiariausi ir perspektyviausi iš šių degalų tuo laikotarpiu šalyje tapo pirmos kartos biodegalai - biodyzelinas ir bioetanolis bei ịvairios koncentracijos jų mišiniai, todèl praktikoje jų gamybos ir naudojimo galimybiu tyrimams buvo skiriama daugiausia dèmesio. Besikuriant biodegalų pramonei, laboratorijoje buvo išnagrinèti ir praktiniu požiūriu įvertinti Lietuvoje atsinaujinančių energijos išteklių naudojimą skatinantys ES ir LR teises aktai bei norminiai dokumentai, reglamentuojantys biodegalų gamybą, ištirtas šalies biodegalų išteklių potencialas, surinkti duomenys apie gamybinius pajègumus šalies imonèse, pateikti atsakymai $\mathfrak{i}$ racionalaus sprendimo reikalaujančius biodegalų gamybos klausimus.

Pagrindinis juridinis pretekstas biodegalams gaminti buvo $1992 \mathrm{~m}$. priimta Jungtinių Tautų 
klimato kaitos konvencija [30], reglamentuojanti šiltnamio reiškini sukeliančių teršalų emisiją, ir 1998 m. Kioto mieste (Japonija) pasirašytas susitarimas iki $2010 \mathrm{~m}$. klimato atšilimą sukeliančių dujų emisiją sumažinti 5,2 \% (ES šis ịsipareigojimas $-8 \%$, palyginti su $1990 \mathrm{~m}$. lygiu).

2006 m. Europos Komisija paskelbè komunikatą „ES biodegalų strategija“ [31], kuriame nurodè strategines biodegalu gamybos ir naudojimo kryptis. Svarbiausia strategine kryptis buvo pirmosios kartos biodegalų žaliavų bazès plètra ir gamybos technologijų tobulinimas, siekiant mažinti biodegalų savikainą ir neigiamą poveikį aplinkai bei dèl konkurencijos su maisto sektoriumi biodegalams gaminti naudoti maistui netinkamas žaliavas.

Vykdydamas ES direktyvą LR Seimas $2007 \mathrm{~m}$. sausio 18 d. nutarimu Nr. X-1046 patvirtino Nacionalinę energetikos strategiją, kurioje numatyta, kad iki $2020 \mathrm{~m}$. biodegalai turètų sudaryti $15 \%$, o iki 2025 m. $-20 \%$ bendro transportui skirto degalų kiekio. Iš pakankamai plačios biodegalų gamos Lietuvoje gaminamas ir naudojamas biodyzelinas ir bioetanolis, kuris paklausus ir bioetiltretbutileterio (bio-ETBE) gamyboje. Ilgą laiką Lietuvoje veike viena biodyzelino ir viena bioetanolio gamybos įmonè. Didinant biodegalų gamybą buvo siekiama sukurti jų naudojimo skatinimo politiką, nes kitu atveju artimiausioje ateityje strigs ir juc gamyba. Skirtingai nuo pakankamai sèkmingos biodegalų gamybos, jų naudojimą stabdo daugelis priežasčių. Viena jų yra absoliučiai techninè, nes negalima íprastiniuose varikliuose naudoti biodegalų mišinius su daugiau kaip $5 \%$ biodegalų, nes kitu atveju transporto priemonems netaikomos automobilių gamintojų garantijos. Specialiai biodegalams naudoti pritaikytų ar pagamintų automobilių šalyje praktiškai nèra (Vİ Regitra duomenimis, $2016 \mathrm{~m}$. registruoti tik 2 etanoliu varomi lengvieji automobiliai).

Ši problema aktuali ne tik Lietuvos biodegalų pramonei, dabar apie tai kalbama ir tarptautiniu mastu (dalis Vokietijos biodyzelino gamybos imonių priverstos mažinti jo gamybos apimtis, nes nèra pakankamos realizavimo rinkos). Todèl Lietuvoje atsinaujinančių energijos išteklių naudojimą skatina LR Akcizų ịstatymas, LR Mokesčio už aplinkos teršimą ịstatymas ir parama ūkininkams už energetinių augalų nustatymą.

Lietuvoje biodegalų gamybą lemia tos pačios problemos, kaip ir visoje ES. LR Žemès ūkio mi- nisterijos duomenimis, iš gana gausaus gamintojų rato šiandien išliko trys modernūs biodegalų gamintojai: bioetanoli gamina UAB „Kurana“ (pajègumai 40 tūkst. $\mathrm{t} / \mathrm{metus}$ ); biodyzeliną - UAB "Mestilla“ (110 tūkst. t/metus) ir UAB „Vaizga“ (30 tūkst. t/metus).

Nepaisant ankstesnių biodyzelino naudojimo augimo prognozių, šiuo metu daugelyje šaliu grynas biodyzelinas nenaudojamas - tik $5 \%$ dalis naudojama mišinyje su mineraliniu dyzelinu, nes grynam biodyzelinui (RME) turi būti pritaikyti varikliai. Tai numato mineralinio dyzelino kokybę apibrèžiantis standartas LST EN 590. Išaugus biodyzelino gamybos apimtims, mūsų šalyje didžioji pagaminto biodyzelino dalis, nesunaudojama mišiniams gaminti, yra eksportuojama.

Analizuojant literatūros šaltinius bei eksperimentinius duomenis patvirtinta, kad aplinkosauginiu ir ekonominiu požiūriais labai svarbu racionaliai panaudoti biodyzelino gamybos procese susidarančius šalutinius produktus ir atliekas, ypač glicerolị. Siekiant sumažinti biodyzelino gamybos savikainą, būtina ieškoti racionalių glicerolio fazès panaudojimo būdų, pavyzdžiui, glicerolio panaudojimas energetinèms reikmèms (kietojo ar skystojo kuro gamyboje) ar kitu nemaistinių produktų gamyboje [32].

Ateities plètros tikslai ir perspektyvos. Praktikoje pastaruoju metu prioritetas alternatyviu degalų srityje teikiamas dujiniams degalams: suspaustoms gamtinėms dujoms, suskystintoms naftos dujoms, vandeniliui ir jų mišiniams. Šiuo metu keičiasi ir ES politika biodegalų atžvilgiu. $2015 \mathrm{~m}$. priimta nauja Europos Parlamento ir Tarybos direktyva (ES) 2015/1513, kuria iš dalies keičiamos direktyva 98/70/EB dèl benzino ir dyzelinių degalų (dyzelino) kokybės ir direktyva 2009/28/EB dèl skatinimo naudoti atsinaujinančių išteklių energiją, skatinti perejjimą nuo biodegalų, gaminamų iš maistinių žaliavų, prie pažangiujų (II kartos) biodegalų, gaminamų iš atliekinių žaliavų, gamybos ir naudojimo. Šiai plètros krypčiai Lietuvoje iškyla daug keblumų, todèl atsiveria naujos veiklos galimybès mokslo institucijoms.

\section{Saulès energetika}

Plètros istorija Lietuvoje ir esama situacija. Pagrindinès saulès energijos panaudojimo rūšys pasaulyje, taip pat ir Lietuvoje, yra saulès šilumos ir saulès šviesos energija. 
Sauless šilumos energija - saulès spindulinè energija, paverčiama ị šilumos energiją saulès kolektoriuose. Duomenys apie šios energijos panaudojimą Lietuvoje nèra išsamūs, nèra institucijos, renkančios šią informaciją. Pagal Europos saulès šilumos pramonès federacijos duomenis [33], $2014 \mathrm{~m}$. Lietuvoje buvo instaliuota $10400 \mathrm{~m}^{2}$ (7 $280 \mathrm{~kW}$ ) saulès karšto vandens ruošimo sistemų (SKVRS), o ES mastu - 31,8 GW.

Viena pirmujų SKVRS sumontuota Kačerginès miestelio vaikų sanatorijoje. Ši projektą igyvendino Švedijos energetikos agentūra (STEM), pasitelkusi savo šalies investicinę klimato programą (SICIP), skirtą energetikos sektoriui tobulinti ir mažinti $\mathfrak{t}$ aplinką išmetamų šiltnamio reiškinị sukeliančių dujų kiekí. Nuo 2002 m. rudens $78 \mathrm{~m}^{2}(55 \mathrm{~kW})$ sistema tiekia šilumą sanatorijos reikmėms. Pademonstruotas integruotas sprendimo variantas - bioenergijos ir saulès energijos kombinacija, kuri, kaip parodè kelių metu eksploatavimo patirtis, yra patikima tiek techniniu požiūriu, tiek ir ekonomine prasme. Ši sistema papildomai per metus gali tiekti $15-20 \%$ viso reikiamo karšto vandens kiekio (vasaros metu - 25$30 \%$ ). Vidutinis metinis pagaminamos šilumos kiekis kolektoriaus ploto atžvilgiu yra $400 \mathrm{kWh} /$ $\mathrm{m}^{2}$. Laboratorijos darbuotojai seke šios sistemos veiklą nuo eksploatavimo pradžios ir pateikè išsamius ekonominius vertinimus [34-36].

Per pastaruosius keletą metų instaliuotos šios stambesnès saulès karšto vandens kolektorinès sistemos:

- Kruonio hidroakumuliacinejje elektrinèje - 79,8 kW (114 m² saulès kolektorių);

- Anykščių miesto ligoninejje - 109,2 kW (156 $\mathrm{m}^{2}$ saulès kolektorių);

- Anykščiu miesto baseine „Bangenis“ $116,2 \mathrm{~kW}$ (166 $\mathrm{m}^{2}$ saulès kolektorių);

- Plungès rajono savivaldybès ligoninèje - 142,8 kW (204 $\mathrm{m}^{2}$ saulès kolektorių).

Vienas svarbiausių etapų įrenginejjant saulès kolektorių sistemą - komponentų parinkimas, t. y. sauless kolektoriai ir jų tvirtinimas, vandens talpos, vamzdynai ir jų izoliavimas, siurblių blokai, automatika. Reikètų rinktis pasaulyje jau žinomų i̇monių produkciją, kuriai suteikiamos ilgalaikès gamintojo, o ne pardavejo garantijos. İsigyjant saulès kolektorių būtina ịsitikinti, kad jis turi akredituotos laboratorijos išduotą Solar Keymark sertifikatą pagal EN 12975 reikalavi- mus - sertifikuotų kolektorių sąrašas pateikiamas [37]. Tai pagrindinis techninis dokumentas, rodantis pagrindines kolektoriaus šilumines ir hidraulines charakteristikas, ir jų reikšmių palyginimai suteikia galimybę pasirinkti tinkamą variantą.

Pastate įrengti saulès kolektoriai tiekia karštą vandeni, bet pastatas taip pat gauna didelę dali energijos iš saulès per jo skaidrias ir nepermatomas atitvaras. Būtina skaičiuoti šilumos pritekejjimus iš išorès į pastatą, ịvertinus saulès ir dangaus skliauto ilgabangę spinduliuotę. Taip pat vasaros metu gyvenimo komfortui užtikrinti reikia vertinti ir vessinimo klausimus. Aplinkos ministerijos Statybos produkcijos sertifikavimo centras (SPSS) išdavè instituto darbuotojams licencijas pastatų energinio naudingumo modeliavimo programoms (NRG 3), galinčioms modeliuoti AEI (saulès, biomasès, vejjo ir šilumos siurblių) panaudojimo galimybes ịvairios paskirties pastatuose.

Saulès šviesos energija - iš saulès šviesos tiesiogiai gaunama elektros energija. Šią energiją Lietuvoje pradèta intensyviai issisavinti nuo $2012 \mathrm{~m}$., kai gerokai padidinus supirkimo tarifą elektrinių galia 2012-2014 m. išaugo nuo 0,525 iki $69 \mathrm{MW}$, o gaminamos elektros energijos kiekis - atitinkamai nuo 0,584 iki $73 \mathrm{GWh}$. Lietuvoje veikiančios didžiausios saulès elektrinès: Sitkūnų saulès energijos parkas (2,56 MW), Brizgų saulès fotoelektrinių parkas $(1,99 \mathrm{MW})$, Daušiškių saulès fotoelektriniu parkas (1,96 MW), „Solar LT“ saulès elektrinè (1,48 MW).

Populiariausias ekonominès veiklos skatinimo būdas - supirkimo tarifas, jei jis pakankamai laiku padengia jègainès statytojo investicijas ir leidžia šiek tiek uždirbti. Tik tuo atveju rinkos dalyviai rizikuoja savo lèšas investuodami i saulès elektrines. Jei skatinimas per menkas, tai procesas vos juda, bet jei skatinimas didelis, investuojama daug lèšu - vyksta saulès elektrinių instaliuotos galios šuolis. $2015 \mathrm{~m}$. šalyje jau buvo 1968 elektrinès su 70,2 MW instaliuota galia ir 73,34 GWh metine elektros energijos gamyba. Daugiausia tokių elektrinių atsirado Mažeikių rajono (>240 vnt.) ir Vilniaus miesto savivaldybèse (>130 vnt.). Pagrindinę dalį ( 85 \%) Lietuvoje ịrengtų saulès elektrinių sudaro polikristaliniai, o likusią dali - monokristaliniai fotomoduliai. 
Ekonominiai aspektai. Požiūris ị saulès energetiką kiekvienais metais gereja, ir gyventojai vis daugiau domisi saulès kolektorių sistemomis bei jų teikiama nauda, bet spartesnę plètrą stabdo santykinai didelè šių sistemų kaina ir ilgas atsipirkimo laikas. Nevertinant valstybès paramos, vidutinis saulès sistemų atsipirkimo laikas daugiabutyje yra apie 10 metų ir priklauso nuo daugelio veiksnių - įrengtos sistemos tipo, centralizuotai tiekiamos šilumos kainos, tinkamos sistemos eksploatacijos. Gyventojai, renovuojantys pastatus ir norintys ịsidiegti alternatyvius energijos išteklius, turètų pateikti papildomus reikalavimus investicinių planų rengejjams.

Jau keletą metų Lietuvos aplinkos apsaugos investicijų fondas teikia paramą saulès sistemoms irengti. Individualiuose gyvenamosios paskirties pastatuose teikiama $30 \%$ kompensacinè išmoka, o visuomeninès paskirties pastatuose (mokyklos, ligoninès, sanatorijos ir kt.) skiriama 50-100\% subsidija. Instituto mokslininkai analizavo įvairių dydžių saulès sistemas, skaičiavo jų atsipirkimo laikus, pagamintos energijos kiekius, $\mathrm{CO}_{2}$ emisiju mažinimo mastus ir pateike nemažai išvadų bei rekomendacijų [38-42].

Laboratorijos darbuotojai taip pat tyrinèjo saulès šilumos panaudojimą CŠT sistemose. Skaičiavimuose, atliktuose poros nedidelių Lietuvos miestų pavyzdžiu, buvo vertinamas saulès kolektorių sistemų ekonominis tikslingumas. Šiluma gaminama ir tiekiama tiesiai $\mathfrak{i}$ tinklus ar naudojant šilumos talpyklas vasarą, o žiemą - deginant biokurą. Analizè parodè, kad tik vasarą su šilumos talpykla įmanoma visiškai patenkinti šilumos poreikius, o kitais sezonais reikètų papildomai gaminti šilumą naudojant biokuro deginimo technologiją. $2014 \mathrm{~m}$. atlikti ekonominiai skaičiavimai atskleide, kad vidutiniai šilumos gamybos kaštai su kapitalo kaštais investicijoms yra 23,5-24,8 €/MWh, o tai daugiau nei šilumos gamybos kaina i̇monèje [43]. Net 10 \% sumažinus investicijų dydị ị sistemą, gaunami šilumos gamybos kaštai siekia 23,324,1 €/MWh, todèl laikoma, kad investicijos nèra ekonomiškai naudingos be paramos. Tačiau, jei biokuro kaina ateityje augs, ilgalaikèje perspektyvoje saulès šildymo sistema galiausiai gali pasirodyti esanti ekonomiškas sprendimas, nes iš gamybos kainos iškrinta kuro dedamoji. Pasaulinis biokuro poreikis gali priversti augti biokuro kainas ateityje, o tada bus ekonomiška pakeisti dali biokuro í saulès šilumą, taip pat eksportuoti dalị biokuro ị kitas šalis.

Ateities plètros tikslai ir perspektyvos. Nuo 2015 m. šios srities elektros energijos gamybos plètra praktiškai sustojusi, nors galimybiu jai yra, pakanka ir technologinių sprendimų rinkoje. Igyvendinant ES direktyvą 2010/31/ES dèl pastatų energinio naudingumo, pagal LR teisès aktus bus reikalaujama, kad nuo $2016 \mathrm{~m}$. lapkričio $1 \mathrm{~d}$. visi naujai statomi pastatai atitiktų A energinio naudingumo klasę. Tai suteiks papildomą paskatą naudoti mažos galios saulès elektrines urbanizuotoje aplinkoje. Šiuo metu Vyriausybès nustatyta tvarka ir sąlygomis ne didesnès nei $10 \mathrm{~kW}$ ịrengtosios galios elektrinèse pagaminta perteklinè elektros energija superkama už nustatytą fiksuotą tarifą.

Nuo 2015 m. Lietuvoje pradejjo veikti elektros energijos dvipusès apskaitos sistema. Tai skirstomojo elektros tinklo operatoriaus administruojama sistema, kurios privalumais gali naudotis tik gaminantys vartotojai, kurių namų valdos prieigose yra įrengtos ne didesnès kaip $10 \mathrm{~kW}$ galios, o biudžetinių ir viešųų ịstaigų statiniuose - ne didesnès kaip $50 \mathrm{~kW}$ galios jègainès - saulès šviesos energijos elektrinès. Straipsnio autorių skaičiavimais, ịvertinus nustatytą elektros tinklų naudojimosi kainą, iki $10 \mathrm{~kW}$ galios jègainè atsipirktų per 11-12 metų. Kainai didejjant, atitinkamai išaugtų ir atsipirkimo laikas.

Saulès šilumos naudojimas centralizuotai šilumos gamybai palaipsniui skverbiasi į Europos miestuose išvystytus centralizuoto šilumos tiekimo tinklus, kur yra vietos sumontuoti dideli plotą užimančius saulès kolektorius ir šilumos saugyklas. Ši sistema jau dabar patraukli ir pletojama Danijoje, Vokietijoje, Švedijoje, kur yra dideli valstybiniai iškastinio kuro mokesčiai. Pati saulès kolektorių sistema nèra konkurencinga be sezoninès talpyklos, tačiau pastaroji itin kilsteli investicijų poreiki. Lietuva, panaudojusi ES paramą biomasès katilams ir įrenginiams keisti, gamina gana pigią šiluminę energiją. Saulès kolektorių su sezoninemis talpyklomis sistemos CŠT tinkluose pareikalautų didelių investicijų ir valstybès subsidijų, bet jos būtų perspektyvios tik padidèjus gamtinių dujų ir biomasès kainai bei sugriežtėjus aplinkosauginiams reikalavimams. 


\section{Vèjo energetika}

Plètros istorija Lietuvoje ir esama situacija. Lietuvai atgavus nepriklausomybę, elektros energijos gamyba buvo perteklinè ir nebuvo planuojami nauji generatoriai, taip pat ir vejjo elektrinès (VE). Apsiribota tik vejjo energijos techninio potencialo tyrimais šalyje [44-49]. Vykdant Jungtinių Tautų plètros programos (UNDP) Baltijos šalių vẻjo energetikos plètros programos rengimo darbus $2000 \mathrm{~m}$. buvo ịvertintas Lietuvos vejo energijos potencialas [50]. Šio energetikos sektoriaus skatinimo sistemos sukūrimas bei prioritetinių zonų jos plètrai iteisinimas paskatino vejo energetikos spartų šuolị [51-53].

Pirmoji moderni $630 \mathrm{~kW}$ galios vejjo elektrinè pastatyta Vydmantuose (2004). $2006 \mathrm{~m}$. irengtas pirmasis VE parkas, susidedantis iš penkiolikos 2 MW galios elektrinių. Iki $2015 \mathrm{~m}$. pabaigos buvo įrengta 17 VE parkų, kurių galia sudarè $424 \mathrm{MW}$.

KTU mokslininkų atliktoje "Atsinaujinančius energijos išteklius naudojančių elektrinių prijungimo prie $330-110 \mathrm{kV}$ elektros perdavimo tinklo iki 2030 m. galimybių" studijoje [54] buvo vertinti vejo energetikos plètros scenarijai. Planuojant vejo elektrinių plètrą, pagrindiniame plètros scenarijuje numatyta $500 \mathrm{MW}$ galia, tarpiniame scenarijuje - iki $670 \mathrm{MW}$, ambicingame - iki 840 MW. Vèjo elektrinių parkuose pagaminta elektros energija $2015 \mathrm{~m}$. sudare apie 6,8\% visos Lietuvoje sunaudojamos elektros energijos. Pagrindinio plètros scenarijaus atveju vèjo energetikos dalis galutiniame elektros energijos sunaudojime sudarytų apie $10 \%$.

Vẻjo elektriniu įtaka aplinkai. Vejjo energija pakeičia organinị kurą, naudojamą elektros energijai gaminti. Vejo elektrinių poveikis aplinkai yra santykinai nedidelis, palyginti su kitomis tradicinèmis jègainèmis. Vejjo elektrinèse pagaminta $1 \mathrm{kWh}$ elektros energijos leidžia išvengti: $\mathrm{CO}_{2}-850,0 \mathrm{~g}$, $\mathrm{SO}_{2}-2,9 \mathrm{~g}, \mathrm{NO}_{\mathrm{x}}-2,6 \mathrm{~g}$, dulkių - 0,1 g, šlako ir lakiųjų pelenų - $550 \mathrm{~g}$.

Pagrindinis poveikis aplinkai arba vèjo energetikos priimtinumas vertinamas atsižvelgiant $i$ šiuos veiksnius: triukšmą, vizualųji (estetinį) poveikį, ịtaką gyvūnijai, augalijai ir gamtinèms buveinèms, elektromagnetinius trikdžius, aplinkos teršimą, reljefo formos suardymą (eroziją), šešèliavimą ir šviesos atspindèjimą.

Vèjo energijos ekonominiai ir socialiniai aspektai. Vejo energetikos projektų ekonominị gyvybingumą nusako pagamintos elektros energijos gamybos kaštai, kurie yra kintantis dydis. Juos veikia keletas svarbiausių parametrų: vejjo parametrai elektrinès įrengimo vietoje, kapitalinès investicijos vejo elektrinei įrengti dydis, kapitalo palūkanos, vejjo elektrinès efektyvumas, elektrinès eksploatacijos kaštai. Investicijos vejjo elektrinei įsigyti sudaro apie $80 \%$ visos projekto investicijos. Vejo energijos lyginamųjų kaštų sumažejimui esminès įtakos turi spartus kapitalinių išlaidų elektrinių gamybai mažejimas per pastaruosius dešimtmečius. Per 10 metų šie kaštai sumažèjo $50 \%$ (2 lentelè).

2 lentelè. Vejjo energetikos pagrindinių ekonominių rodiklių raida ir prognozè iki $2020 \mathrm{~m}$. [5]

\begin{tabular}{c|c|c}
\hline Metai & Investicijos, $\boldsymbol{\epsilon} / \mathbf{k W}$ & Energijos kaštai, EURct/kWh \\
\hline 2003 & 823 & 3,88 \\
\hline 2005 & 746 & 3,61 \\
\hline 2010 & 623 & 2,93 \\
\hline 2020 & 497 & 2,34 \\
\hline
\end{tabular}

Europos Komisijos ExternE projekto tyrimu duomenimis, vejo energijos panaudojimas reikalauja beveik tokių pačių kapitalo investicijų, kaip ir branduolinès energijos, tačiau nereikia jokių kuro sąnaudų. Pagal gamybinių kaštų lygi vejjo elektrinių energija konkurencinga iprastiniu būdu pagamintai elektros energijai. Tačiau, ivvertinus išorinius kaštus, ji akivaizdžiai pranašesnè prieš kitus jos gamybos būdus. Tad Europos vejo energijos asociacijos ir Greenpeace paskelbtame bendrame dokumente prognozuojamas tolesnis spartus vejjo pramonès augimas, lyginamųjų investicijų mažejimas, vejjo elektros kainos mažejimas ir spartus naujų darbo vietų augimas vejo pramoneje.

Ateities plètros tikslai ir perspektyvos. LR Energetikos ministerija Seimui yra pateikusi Atsinaujinančių išteklių energetikos ịstatymo pakeitimo projektą, kuriame numatyta vejjo elektrinių bendrą įrengtąją galią iki $2020 \mathrm{~m}$. padidinti iki 750 MW. Sprendžiant iš AB „Litgrid“ sudaryto perdavimo tinklo laisvų prijungimo galių žemèlapio, geriausios vejjo energetikos plètrai vietos, t. y. pajūrio zona, praktiškai yra išnaudotos, todèl ateityje turi būti numatytos naujos teritorijos arba plečiamas ir stiprinamas perdavimo tinklas. 
2016 m. Lietuvos kariuomenès vado ịsakymu buvo patvirtintas vejo elektrinių projektavimo ir statybos darbus ribojantis žemèlapis, lemiantis didesnes investicijas rengiant projektus ir dar labiau apsunkinantis tolesnę vejjo energetikos plètrą Lietuvoje.

Nepaisant šių apribojimų skaičiavimai rodo, kad vejjo elektrinių parkuose gaminama elektros energija yra pigiausia (be Kauno hidroelektrinès gaminamos energijos), palyginti su visomis kitomis naujomis elektrinèmis, todèl siekiant igyvendinti planuojamus AIE plètros rodiklius tolesnè elektros energijos gamybos iš AIE technologijų plètra siejama su vejjo energetika sausumoje ir jūroje.

\section{Aeroterminè, geoterminè, hidroterminè ir liekamoji energija}

Plètros istorija Lietuvoje ir esama padètis. Pastaraisiais dešimtmečiais institute vykdyti energijos pernešimo procesų šilumos siurbliuose teoriniai ir eksperimentiniai tyrimai, Stirlingo ciklu veikiančių šilumos siurblių projektavimo ir konstravimo darbai, šilumos siurblių, naudojančių grunto, vandens ir oro šilumą diegimo galimybių tyrimai, parašytos ir apgintos kelios disertacijos šilumos siurblių tema [55-64].

Aerotermine energija - šilumos energija, susikaupusi ore. Aplinkos ore esančios šilumos ištekliai neišsemiami, tačiau Lietuvoje dèl ịvairių objektyvių priežasčių jie nebuvo plačiai naudojami. Tik pastarajji dešimtmetị, kai ịvairios užsienio firmos pateikè ị rinką naujos kartos šilumos siurblius, veikiančius Lorentco ciklu ir kaip darbo agentą naudojančius R744 ( $\mathrm{CO}_{2}$ dujas), Lietuvoje imta sparčiau plètoti aeroterminès energijos panaudojimą.

Geotermine energija - šilumos energija, susikaupusi žemiau žemès paviršiaus. Geoterminès energijos ištekliai pasiskirstę visoje Lietuvos teritorijoje, tačiau didžiausias jų potencialas, leidžiantis statyti keliolikos MW šiluminès galios jegaines, yra Vakarų Lietuvoje. 1989 m. pirmieji geoterminiai gręžiniai Lietuvoje išgręžti Vydmantuose, jų gylis daugiau kaip du kilometrai. Gręžiniai išbandyti 1993-1994 m., pasiekta geoterminio vandens temperatūra $74^{\circ} \mathrm{C}$, tačiau bankrutavus Vydmantų daržininkystès ūkiui - pagrindiniam šilumos vartotojui - jègainé nebuvo pastatyta.
$1991 \mathrm{~m}$. siekiant plètoti geoterminès energijos gamybos tyrimus, Žemès gelmių šilumos išteklių tyrimą, tobulinti jos išgavimo technologijas bei visapusiškai ir kompleksiškai panaudoti žmogaus ūkinèje veikloje, buvo įkurta įmone „Geoterma“. 1995 m. gruodžio 22 d. LR Vyriausybès nutarimu Nr. 1609 įsteigtai UAB „Geoterma“ pavesta statyti Klaipèdos pavyzdinę geoterminę jègainę ir tiekti šilumą Klaipedos miesto šilumos tinklams. Tik $2004 \mathrm{~m}$. birželį Klaipèdos geoteminè jègainè pripažinta tinkama naudoti $35 \mathrm{MW}$ galią: 13,6 MW šilumos iš geoterminio vandens ir 21,4 MW iš vandens šildymo katilų, kuriuose deginamos gamtinės dujos, karšto vandens (absorbcinių šilumos siurblių varomoji energija).

Ši i̇moné buvo geras mokslo tyrimų rezultatų taikymo šilumos energetikoje pavyzdys, tačiau ilgainiui jègainès ekonominis naudingumas nebuvo užtikrintas. Bendrovès užsakymu tęsiami moksliniai tyrimai panaudojant iš žemès gelmių išgautą geoterminị ir mineralinị vandenị šildymo, rekreacijos objektų kūrimo ir kitiems tikslams.

Hidrotermine energija - šilumos energija, susikaupusi paviršiniuose vandenyse. Tai upių, ežerų, dirbtinių tvenkinių vandenyje sukaupti šilumos ištekliai. Jų panaudojimą lemia įvairios priežastys, pavyzdžiui, kad žiemos metu vandens temperatūra po ledu tèra tik $\sim+1{ }^{\circ} \mathrm{C}$. Instituto darbuotojų straipsnyje [65] pateikti išsamūs Lietuvos upių šilumos išteklių ir jų daugiametès kaitos tyrimų rezultatai.

Liekamoji energija - technologinio proceso metu išsiskirianti energija, kuri nepanaudojama tame procese. 1995-2011 m. ši energija teisès aktuose vadinta ivvairiai: nuo $1995 \mathrm{~m}$. - antriniai energijos ištekliai; nuo 1997 m. - šalutiniai energijos ištekliai; nuo 1998 m. - atliekiniai energijos ištekliai; nuo 2011 m. - liekamoji energija.

1991-2002 m. institute atlikta daug tiriamujuc darbų, kuriuose analizuota informacija apie Lietuvos pramonès ir energetikos i̇monèse susidariusius liekamosios energijos išteklius, ịvertintos miestų nuotèkų valymo įmonių nuotèkų šilumos pasisavinimo šilumos siurbliais ir jos perdavimo i tų miestų centralizuoto šilumos tiekimo tinklus galimybès [64].

Šių tyrimų apibendrinti rezultatai pateikti Nacionalineje energijos naudojimo efektyvumo didinimo 2006-2010 m. programoje [67]. Joje nurodyta, kad bendras liekamosios energijos potencialas 
šalies pramonès, energetikos ir nuotèkų valymo įmonese - apie 7,5-10,5 TWh per metus. Šiu ištekliu panaudojimo techninis potencialas - apie 5-6,5 TWh per metus. Liekamosios energijos išteklių panaudojimo ekonominis potencialas - apie 4 TWh per metus.

Geriausias liekamosios energijos panaudojimo pavyzdys - AB „Lifosa“, kuri nuo 1998 m. rudens, panaudodama sieros rūgšties gamybos cecho liekamosios energijos išteklius, tiekia šilumą Kèdainių miestui, praktiškai patenkindama miesto centralizuotos šilumos poreikị. Nuo $2000 \mathrm{~m}$. naudodama liekamosios energijos išteklius i̇monè savoms reikmèms gamina elektros energiją, $o$ perteklių parduoda.

Šilumos siurblių naudojimas. Lengviausiai Lietuvoje ịsisavinami arti Žemès paviršiaus esantys, vadinamieji seklieji geoterminiai ištekliai, kurie vartotojui tiekiami šilumos siurbliais. Šilumos siurblių panaudojami šilumos ištekliai glūdi iki 100-150 m gylyje ir jų potencialas didžiulis. Daugeliu atvejų šilumos siurbliai naudojami individualiuose pastatuose, tačiau yra ir daugiabučių namų, kuriuose dalis karšto vandens poreikių patenkinama naudojant geoterminę energiją.

3 lenteleje parodytas šilumos siurblių sektoriaus rinkos augimas Lietuvoje ir visose ES šalyse 2005-2014 m. [66].

Šilumos siurbliai sèkmingai naudojami ir komerciniuose objektuose - paslaugų bei pramonès įmonèse. Druskininkų sveikatingumo ir poilsio komplekse „Grand SPA Lietuva“ 2010 m. ìdiegtos energetikos ir šildymo sistemos su šilumos siurbliais, naudojančiais giluminių gręžinių (iš viso $200 \mathrm{~m}$ gylio 147 gręžiniai) geoterminę šilumą, aplinkos oro šilumą ir nuotekų iš mineralinio vandens vonių šilumą. Geoterminio šildymo sistemos, projektuotos ir įrengtos UAB „TENKO Baltic“, šiluminè galia 1,79 MW. Šio geoterminio šildymo projekto vertè - $1,74 \mathrm{mln}$. $€$.

Kompanijų grupès „BOD group“ aukštųjų mokyklų tyrimų centras nuo $2013 \mathrm{~m}$. veikia Visorių informacinių technologijų parke Vilniuje.
4 aukštų pastato bendras plotas $28833,71 \mathrm{~m}^{2}$, o šildomas plotas - $21994 \mathrm{~m}^{2}$. Pastate su naujausios kartos vokiška SINGULUS įranga vykdoma lietuviškų saulès elementų gamyba ir technologiniai tyrimai. Pastate įrengta viena didžiausių geoterminio šildymo ir vesinimo sistemų Lietuvoje $(0,8 \mathrm{MW})$. Saulès elementų gamybos linijoms vésinti geoterminè energija naudojama ištisus metus. Po pastatu išgręžti šimtas devyni 150 m gylio gręžiniai, įrengta 12 Stiebel Eltron WPF $66(70 \mathrm{~kW})$ šilumos siurblių. Veiksmingai naudojant geoterminę šilumą suprojektuotas ir instaliuotas žemos temperatūros grindinis šildymas (vandens temperatūra iki $40{ }^{\circ} \mathrm{C}$ ). Siurbliams reikalingą elektros energiją tiekia ant stogo įrengti saulès šviesos elementai. Geoterminè energija sudaro apie $43 \%$ visos per metus sunaudojamos šiluminès energijos, kita dalis gaunama iš Vilniaus miesto šilumos tinklų.

Ekonominiai aspektai. 2012 m. išaugusi centralizuotai tiekiamos šilumos kaina paskatino atlikti šilumos siurblio, naudojančio geoterminę gręžinių šilumos energiją, diegimo daugiabutyje gyvenamajame name galimybiu techninį-ekonominị vertinimą. Pasirinktas 5 aukštų, 70 butu, $1981 \mathrm{~m}$. statybos blokinis gyvenamasis namas Sukilèliu pr. 82, Kaune, kurio šildomas plotas - 3383,55 $\mathrm{m}^{2}$. Pastatas iš dalies atnaujintas. Šilumos sąnaudos pastatui šildyti: 2011 m. - 98,14 kWh/m²/šild. sez.; 2012 m. $104,7 \mathrm{kWh} / \mathrm{m}^{2} /$ šild. sez.

Pasirinktas švedų firmos „NIBE Energy Systems" gamybos NIBE TM F1345-60 šilumos siurblys, naudojantis šilumą iš geoterminių gręžinių. Bendras aktyvus gręžinių ilgis $1068 \mathrm{~m}$. Skaičiavimai parode, kad įrengus šilumos siurblit, per metus jis pagamintų $65 \%$ visos reikalingos šilumos energijos ir atsipirktų per 3,3 metu (2012 m. vertinimu). Mažèjant centralizuotai tiekiamos šilumos kainai, šilumos siurblio atsipirkimo rodikliai prastèja: $2014 \mathrm{~m}$. vertinimu atsipirkimo laikotarpis siektų 5,9 metų.

Ateities plètros tikslai ir perspektyvos. Šilumos siurblių diegimo skatinimas numatytas

3 lentelè. Šilumos siurblių sektoriaus rinkos augimas Lietuvoje ir ES šalyse 2005-2014, vnt.

\begin{tabular}{c|c|c|c|c|c|c|c|c|c|c}
\hline & $\mathbf{2 0 0 5}$ & $\mathbf{2 0 0 6}$ & $\mathbf{2 0 0 7}$ & $\mathbf{2 0 0 8}$ & $\mathbf{2 0 0 9}$ & $\mathbf{2 0 1 0}$ & $\mathbf{2 0 1 1}$ & $\mathbf{2 0 1 2}$ & $\mathbf{2 0 1 3}$ & $\mathbf{2 0 1 4}$ \\
\hline Lietuva & 0 & 0 & 0 & 0 & 554 & 517 & 597 & 645 & 719 & 1095 \\
\hline Ǐ̌ viso ES šalyse & 406652 & 532218 & 584596 & 800793 & 734282 & 800388 & 808591 & 750436 & 769878 & 795562 \\
\hline
\end{tabular}


LR atsinaujinančių išteklių energetikos įstatyme Nr. XI-1375 ir Klimato kaitos specialiosios programos lèšu naudojimo tvarkos apraše, patvirtintame LR aplinkos ministro $2010 \mathrm{~m}$. balandžio 6 d. įsakymu Nr. D1-275 (Žin., 2010, Nr. 422040).

Pastaraisiais metais igyvendinta nemažai projektų daugiabučiuose namuose, kurių metu įdiegtos geoterminès energijos panaudojimo patalpoms šildyti ir karštam vandeniui ruošti sistemos.

Aeroterminè energija taip pat vis plačiau naudojama visuomeninès paskirties pastatų šildymo-vedinimo sistemose. Tikètina, kad tokios plètros tendencijos išliks ir ateityje.

\section{Hidroenergija}

Plètros istorija Lietuvoje ir esama situacija. Pirmosios hidroelektrinès nepriklausomoje Lietuvoje buvo pastatytos 1919, 1922 ir 1924 m., o $1922 \mathrm{~m}$. profesorius S. Kolupaila apskaičiavo svarbesnių Lietuvos upių vidutinę galią - 199,5 MW. Inžinierius J. Smilgevičius 1929 m. pateikè siūlymą statyti hidroelektrines prie 20 upių, isskaitant $\mathrm{Ne}$ muną ir Nerị. Iš viso buvo siūloma statyti $86 \mathrm{HE}$, kurių bendroji galia siektų 113,4 MW ir 773 GWh elektros energijos gamybos per metus. Bègant metams, mažosios hidroelektrinès taip pat nebuvo užmirštos, $1935 \mathrm{~m}$. jų buvo 96 , o bendroji galia siekè 1932,2 kW, metinis elektros energijos išdirbis $-0,836 \mathrm{mln}$. $\mathrm{kWh}$, tai sudare tik $0,11 \%$ visos šalyje pagaminamos elektros energijos [68].

Antrojo pasaulinio karo metu dauguma $\mathrm{HE}$ Lietuvoje buvo sunaikintos, tačiau po karo Lietuvos hidroenergetikai skirtas demesys, apskaičiuota mažų ir vidutinių Lietuvos upių hidroenergijos galia - 56 MW (1946) ir 118 MW (1950). 1951 m. pateiktas hidroelektriniu ant Nemuno projektas, $1955 \mathrm{~m}$. rugsèji šis projektas buvo pradètas igyvendinti (prie Kauno). Tuo pačiu metu buvo atstatomos ir senosios per karą sugriautos mažosios HE, o kartu prasidèjo naujų statyba, $1958 \mathrm{~m}$. jau veikè 104 hidroelektrinès. Kauno hidroelektrinès statyba baigta 1960 m., instaliuota galia sieke 90 MW.

Instituto darbuotojai J. Jablonskis ir M. Lasinskas 1962 m. parengè leidini [69], kuriame pateikè Lietuvos upių nuolydžių, vidutinių daugiamečių debitų, galingumų, hidroenergetinių rodiklių duomenis.

Nuo 1954 m. Lietuvos elektrifikavimas buvo pradètas per šalies elektros tinklus, daug mažųjų elektrinių tapo neekonomiškos, dauguma jų buvo uždarytos 1959-1981 m., tačiau Kauno HE veike visą ši laiką, o jos galia buvo padidinta iki $101 \mathrm{MW}$.

Atkūrus Lietuvos nepriklausomybę, hidroenergetikai skirta daugiau demesio, HE svarba buvo populiarinama spaudoje, televizijoje, įvairiuose susirinkimuose. 1997 m. jau veikè 18, 1999 m. - 30, o 2004 m. - net 77 mažosios HE, jų bendra galia siekè 21,3 MW. Po $2004 \mathrm{~m}$. HE statybų sparta pamažu sumenko, $2010 \mathrm{~m}$. veikè 89 mažosios HE. Šiuo metu Lietuvoje veikia 98 mažosios HE, kurių bendra galia sudaro 26,73 MW. 2011 m. LR Atsinaujinančių išteklių energetikos ịstatyme nurodoma, kad bendrą hidroelektrinių galią (įskaitant Kauno A. Brazausko HE) iki 2020 m. planuojama padidinti iki $141 \mathrm{MW}$ [67].

Lietuvoje yra tik viena didelès galios ( $>10 \mathrm{MW}$ ) hidroelektrinè - Kaune, kuri pagamina 300400 GWh elektros energijos per metus, tai sudaro apie 4-6\% visos sunaudojamos elektros energijos Lietuvoje, tačiau atsižvelgiant $\mathfrak{i}$ technines-ekonomines galimybes šalyje yra panaudota apie 25$35 \%$ vandens išteklių [69]. Be elektros energijos gamybos, Kauno HE atlieka kitą svarbų vaidmeni - apsaugo Kauno miestą nuo potvynių. Be to, Kauno marios (ežeras, susidaręs dèl HE patvankos) yra itin populiarus rekreacijos ir traukos objektas.

Mažosios hidroelektrinès pagamina vidutiniškai 60-80 GWh elektros energijos per metus, tai sudaro mažiau kaip $1 \%$ visos sunaudojamos elektros energijos šalyje.

Hidroelektrinių instaliuota galia Lietuvoje pastarajji dešimtmetị mažai kito, didžiosios hidroelektrinès (>10 MW) sudare $101 \mathrm{MW}$, mažesnès galios $(<10 \mathrm{MW})$ - apie $27 \mathrm{MW}$ per pastarajji dešimtmeti (1 pav.).

Ekonominiai aspektai. Hidroenergetika yra vienas seniausių ir pigiausių elektros energijos gamybos būdų. Vertinant hidroelektrines ekonominiu aspektu pagal fiksuotą supirkimo tarifą, jos skirstomos į grupes pagal įrengtąją galią: $\leq 10 \mathrm{~kW}$, $10-1000 \mathrm{~kW}$ ir $>1000 \mathrm{~kW}$. Suteikiamas fiksuotas elektros energijos supirkimo tarifas atitinkamai 0,069, 0,062 ir 0,054 €/kWh. Palyginus su kitoms AEI technologijoms suteikiamu tarifu, žemesnis tarifas yra suteikiamas tik biomasès jègainèms (eksploatuojamos elektrinès rekonstrukcija), toks pats tarifas suteikiamas energijai, pagamintai didelèse vëjo elektrinèse (4 pav.). Sąlyginai pigią hidroelektrinèse pagaminamos energijos kainą lemia tai, 


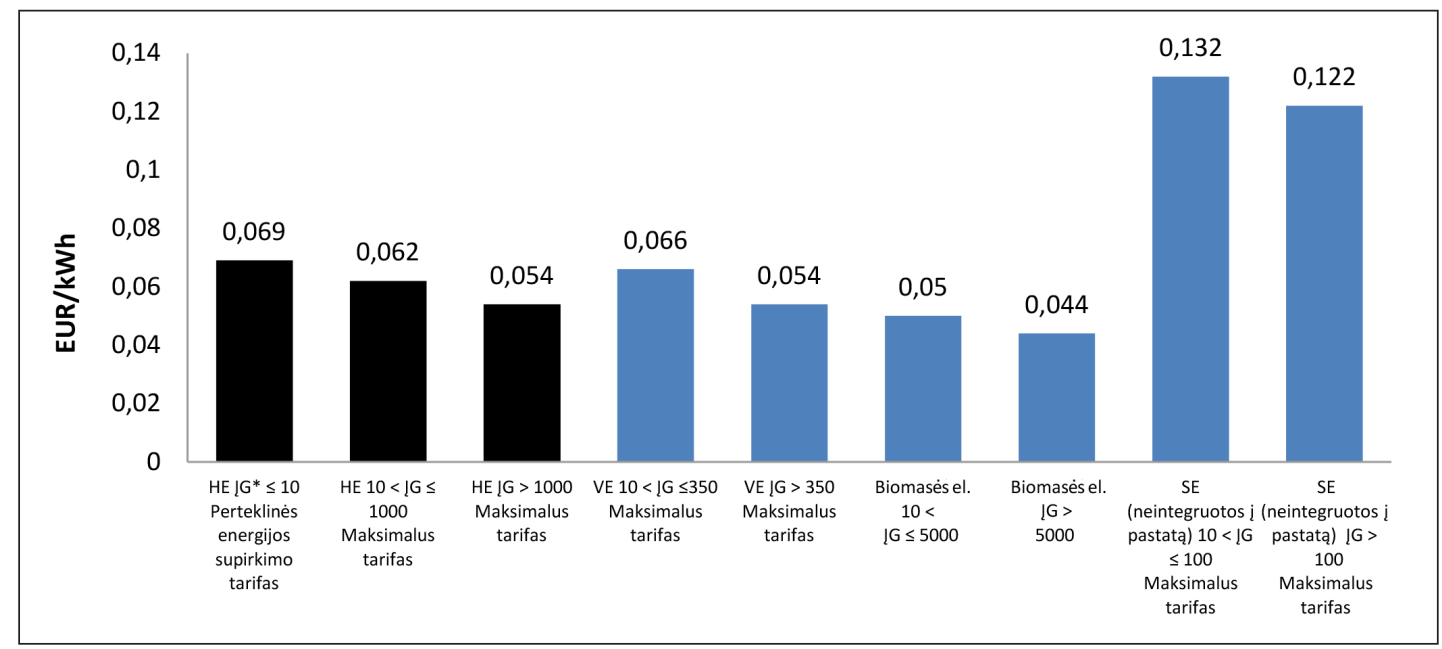

\section{Šaltinis: www.regula.It}

4 pav. Elektros energijos, generuojamos iš atsinaujinančių ištekliu, fiksuotas supirkimo tarifas $2016 \mathrm{~m}$. II ketv.

kad hidroelektrinių technologijos yra pakankamai seniai ištobulintos ir nesudètingos, tačiau reikalaujančios užlieti pakankamai didelius žemès plotus.

Vertinant hidroelektrines socialiniu-ekonominiu požiūriu, svarbu vertinti sukuriamas darbo vietas. 2013 ir 2014 m. duomenimis, mažosios HE sukūrè $<50$ tiesioginių ir netiesioginių darbo vietų. Didelès galios hidroelektrinès (Kauno A. Brazausko HE) sukuria apie 60 darbo vietų Lietuvoje.

Mažųų HE apyvarta $2014 \mathrm{~m}$. sudarè $<5 \mathrm{mln}$. $€$ [5]. Nepaisant ekonominès naudos, tiek moksliniu, tiek ekonominiu požiūriu ịrodyta, kad vandens panaudojimas siejamas ne tik su energetika, bet ir su kompleksinemis paslaugomis, pavyzdžiui, apsauga nuo potvynių, upių vandeningumo padidinimu sausmečio metu, laivyba, vandens turizmu, rekreacijos plètojimu ar kitais papildomais verslais [71, 72]. Šios paslaugos daugiausia siejamos su didelès galios hidroelektrinėmis. Vis delto hidroenergetika turi ir neigiamų pusių. Pagrindinis neigiamas poveikis aplinkai siejamas su didelių sausumos plotų užliejimu, upių ekologinès pusiausvyros sutrikdy$\mathrm{mu}$, biologinès ịvairovés pokyčiais, krantų erozija ir kt.

Ateities plètros tikslai ir perspektyvos. Apibendrinant galima teigti, kad hidroenergetika Lietuvoje nèra itin plačiai naudojama dèl šalyje nepalankių topografinių sąlygų vandens energetikos plètrai. Tai reiškia, kad atsinaujinančių energijos išteklių plètra turi būti pagrịsta ekologinio efektyvumo principu - pirmenybè turi būti teikiama kuo mažesnį neigiamą poveikį turinčioms technologi- joms. Atlikus skaičiavimus nurodoma, kad viena šiuolaikiška vejjo elektrinè gali pagaminti tiek pat elektros energijos, kiek šešios vidutinès galios hidroelektrinès, kurios užtvindytų apie 360 ha plotą. Tokiame pat plote sodinant trumpos rotacijos energetinius želdinius būtų galima gauti beveik dvigubai daugiau energijos nei užliejant didelius žemès plotus [73]. Nors didžiosios hidroelektrinès yra gerokai efektyvesnès už mažąsias, tačiau pagaminamas energijos kiekis nèra adekvatus paveikiamiems žemès plotams, palyginti su kitomis technologijomis. Tai rodo, kad Lietuvoje hidroelektrinès nèra perspektyvios nei ekologine, nei ekonomine prasme. Vis delto tokio tipo energetika, kaip ir visi energijos generavimo įrenginiai, turi ir papildomų teigiamų pusių, pavyzdžiui, kompleksinis upès tvenkinio panaudojimas laivybai, rekreacijai ir kt. Atsižvelgiant ị pagrindinius argumentus už ir prieš bei vertinant ateities perspektyvas galima teigti, kad intensyviau pletoti hidroenergetikos Lietuvoje nèra numatoma.

\section{IŠVADOS}

1. Kietasis biokuras šiuo metu yra Lietuvoje vyraujantis atsinaujinantis energijos išteklius ir numatomas tolesnis jo naudojimo apimčiu didejimas, visų pirma šilumos energetikos sektoriuje. Elektros gamyboje kietojo biokuro naudojimas vis dar turi būti remiamas dèl žemų elektros rinkos kainų ir palyginti didelių investicijų í biokogeneracijos technologijas. 
2. Siekiant plačiau diegti anaerobinio organinių atliekų apdorojimo technologijas šalies kiaulininkystès kompleksuose ir miestų nuotekų valymo imonèse, kartu mažinant biodujų pramonei skiriamą subsidijavimą, mokslininkų bei verslininkų svarbiausias uždavinys yra ieškoti racionalių būdų, kaip didinti biodujų gamybos efektyvumą.

3. Ivertinant pastarujų metų biodegalų pramonès sukūrimo ir plètros patirtí, artimiausioje ateityje būtina atlikti išsamią veiksmų, nulemusių susidariusią gamybos ir naudojimo rinkoje padèti, analizę bei įvertinti biodegalų gamybos iš ne maistui skirtų žaliavų prielaidas - antros ir trečios kartos biodegalų gamybos galimybes, perspektyvas, potencialą bei tikslingumą.

4. Dabartiniu metu saulès šilumos ir saulès elektros energijos gamybos plètra gyvuoja tik šalies piliečių entuziazmo dèka. Reikalingi valdžios politiniai sprendimai dèl paramos. Galimybių plètrai ir technologinių sprendimų rinkoje yra pakankamai.

5. Vejo energetika Lietuvoje generuoja daugiausia elektros energijos, palyginti su kitais AEI, ir yra perspektyviausias plètros šaltinis iki $2030 \mathrm{~m}$. pagal generuojamą galią (iki $840 \mathrm{MW}$ ). Tikètina, kad mažejant investicijų kainai ir energijos kaštams ateityje vejo energetika taps konkurencinga elektros energijos rinkoje ir nebebus remiama.

6. Geoterminès energijos ištekliai pasiskirstę visoje Lietuvos teritorijoje, tačiau didžiausias jų potencialas yra Vakarų Lietuvoje. Nuo 1992 m. geoterminè energija naudota daugiausia individualiuose gyvenamuose namuose, tik pastaraisiais metais imta naudoti daugiabučiuose ir visuomeninès paskirties pastatuose. Perspektyvios yra karšto vandens ruošimo ir elektros energijos gamybos hibridinès sistemos, naudojančios geoterminius, hidroterminius, aeroterminius ir saulès energijos išteklius.

7. Tolesnè didžiųjų ir mažųjų hidroelektrinių plètra Lietuvoje nèra numatoma dèl menko ekologinio efektyvumo. Tai reiškia, kad norint pagaminti energijos vienetą, esant Lietuvos topografinèms sąlygoms, būtų paveikti gerokai didesni žemès plotai nei naudojant kitas atsinaujinančių energijos išteklių technologijas. Tad nei ekonomine, nei aplinkosaugine prasme hidroenergetika Lietuvoje nèra perspektyvi.

8. Atlikus AEI panaudojimo šalies energetikoje analizę galima teigti, kad dèl objektyvių ar subjektyvių priežasčių dauguma AEI buvo plètojami neefektyviai. Tam įtakos galëjo turèti ir valdžios institucijų požiūris į teisinių dokumentų rengimą, kai rezultatai dažnai palankūs atskiroms verslo ar politinèms grupèms, neatitinka visuomenès interesų, kas iš dalies menkino ir komplikavo AEI idejją ir jos igyvendinimą. Ateityje yra tikslinga išanalizuoti priežastis, ịvertinti padarytas klaidas ir numatyti priemones, lemiančias tolygesnę bei efektyvesnę AEI plètrą. Viena iš priemonių būtų nuolatinis glaudus AIE verslo ir mokslo institucijų bendradarbiavimas, užtikrinantis atvirą prieigą prie techninių-ekonominių veiklos rodiklių.

Gauta 20160630 Priimta 20161020

\section{Literatūra}

1. EU 2020 Climate \& Energy Package. 2009.

2. EU 2030 Energy Strategy. 2014.

3. LR Energetikos ministerija. http://enmin.lrv.lt/lt/ veiklos-sritys-3/atsinaujinantys-energijos-istekliai

4. Lietuvos statistikos departamentas. http://osp. stat.gov.lt/

5. Barometer prepared by Observ'ER (FR) in the frame of the "EurObserv'ER 2013-2016".

6. Biokuro potencialo šalyje vertinimas, biokuro kainu prognozé, biokuro panaudojimo socialines naudos ivertinimas ir biokuro panaudojimo pletrai reikalingu valstybes intervenciju pasiūlymai: baigiamoji ataskaita. Vilnius, 2013.

7. Lietuvos mišku ūkio statistika 2015. Aplinkos ministerija, Valstybinè miškų tarnyba.

8. Europos Parlamento ir Tarybos direktyva 2008/1/EB $2008 \mathrm{~m}$. sausio $15 \mathrm{~d}$. dèl taršos integruotos prevencijos ir kontrolès.

9. Šilumos supirkimo iš nepriklausomu gamintoju tvarkos ir sąlygu aprašas. Nutarimas dèl Šilumos supirkimo iš nepriklausomu šilumos gamintoju tvarkos ir sąlygu aprašo patvirtinimo. $2010 \mathrm{~m}$. spalio 4 d. Nr. O3-202, Vilnius.

10. Nepriklausomu šilumos gamintoju gaminamos šilumos rinkos apžvalga už 2016 metu I ketv. Valstybinè kainų ir energetikos kontrolès komisija. Vilnius, 2016.

11. Biokuro birža. http://www.baltpool.lt/lt/kaipveikia-biokuro-birza/ 
12. 2015 m. šildymo sezonas. Biokuro biržos „Baltpool“ prekybos apžvalga.

13. Stasiūnas V. Centralizuoto šilumos ūkio sektoriaus padètis ir ekspertų atlikti darbai $2014 \mathrm{~m}$. bei uždaviniai 2015 metams. Energetikos ekspertu pasitarimas $2015 \mathrm{~m}$. šilumos ūkio sektoriaus uždaviniams aptarti. $2015 \mathrm{~m}$. sausio $12 \mathrm{~d}$.

14. Fortum grupes internetinis portalas Lietuvoje. http://www.fortum.com/countries/lt/pages/default.aspx

15. Hinge J., Perednis E., Faber A., Martikainen A., Nibbi L., Aho M. Unexploited biomass resources - availability and combustion properties. D5.1, May 2011, EUBIONET III report. P. 77.

16. Hinge J., Nikolaisen L., Perednis E., Faber A., Martikainen A., Nibbi L., Alakangas E., Aho M. Agroindustrial residues-availability and combustion characteristics. The 19th European Biomass Conference and Exhibition, June 6-10, 2011, Berlin, Germany. P. 299-301.

17. Tilvikienè V., Venslauskas K., Navickas K., Kadžiulienè Ž. The biomass and biogas productivity of perennial grasses. Žemdirbystè. 2012. Vol. 99. No. 1. P. 17-22.

18. Energetikos ministerija. (2009). Šalies savivaldybèse esamy atsinaujinančiu energijos ištekliu (biokuro, hidroenergijos, saules energijos, geotermines energijos) ir komunaliniu atlieku panaudojimas energijai gaminti: galutinè ataskaita. LEI.

19. Buinevičius K. Biokuras Lietuvos energetikoje. $U A B$ „Enerstena“ Moksliniu tyrimu ir vystymo centro pranešimas seminare „Biokuras Lietuvos energetikoje: kur pletros ribos“. Vilnius: Lietuvos mokslų akademija. 20151029.

20. BPD vertinimu apžvalga. LR finansų ministerija ir UAB „Ekonominès konsultacijos ir tyrimai“, 2010.

21. Verbickas D., Juknys R., Kleišmantas A. Kietojo biokuro naudojimas Lietuvos šilumos gamybos sektoriuje, tolesnès perspektyvos ir poveikis aplinkai. Energetika. 2013. T. 59. Nr. 3. P. 144-152.

22. Kilmés garantiju ataskaitos apie elektros energija, kurios gamybai naudojami atsinaujinantys energijos ištekliai. Elektros perdavimo sistemos operatorius LITGRID, 2016.

23. Proceedings of the UNESCO - University of Tsukuba International Seminar on Traditional
Technology for Environmental Conservation and Sustainable Development in the Asian-Pacific Region. Tsukuba Science City, Japan, 11-14 December, 1995.

24. Biogas production in Germany. SPIN background paper. Umwelt Bundes Amt. 2010.

25. Žemès ūkio informacijos ir kaimo verslo centras, statistinè informacija.

26. Kryževičienė A., Navickas K., Župerka V. Daugiametès žolès biodujų gamybai. LŽŨU mokslo darbai. 2005. Nr. 69(22). P. 76-82.

27. Nauju gamtiniu dujų sistemų, tiesioginiu vamzdynu ir bioduju gamybos įrenginiu prijungimo prie veikiančiu gamtiniu duju perdavimo ar skirstymo sistemu tvarkos ir sąlygu aprašas. LR energetikos ministro $2012 \mathrm{~m}$. birželio $18 \mathrm{~d}$. įsakymas Nr. 1-115.

28. Biokuro gamybos ir naudojimo skatinimo 20042010 m. programa.

29. Mokslinio darbo ataskaita „Degalu su bioetanolio priedais vartojimo vidaus degimo varikliuose tyrimas“, 2007. LEI.

30. Jungtiniu Tautu Bendroji klimato kaitos konvencija, 1992.

31. The EU Strategy on Biofuels: from field to fuel. Volume I: Report. House of Lords, EU Committee. London. 2006.

32. Janulis P., Padgurskas J., Jankauskas V, Makarevičienė V., Sendžikienė E. Kompleksinis aliejaus ir riebalų perdirbimas ị biodyzeliną ir bioalyvas. Rapsu panaudojimo galimybès. 4 tarptautine mokslinè gamybinè konferencija. 2007. P. 51-60.

33. Solar Thermal Markets in Europe. Trends and Market Statistics 2014. June 2015. http://www. estif.org/fileadmin/estif/content/market_data/ downloads/2014_solar_thermal_markets_LR.pdf

34. Katinas V., Karbauskaitė J., Perednis E., Valančius R. Efficiency analysis of combined biomass and solar energy in Lithuania. Clean Technologies and Environmental Policy. 2013. Vol. 15. No. 4. P. 667-676.

35. Šuksteris V., Perednis E. Monitoring operation of renovated heat production, distribution and consumption systems at Kacergine children sanatorium. The 10th International Conference on Solar Energy at High Latitudes NORTH'SUN 2005. May 25, 2005, Vilnius, Lithuania. P. 1-4. 
36. Karbauskaitė J., Perednis E. Kačerginès vaikų sanatorijos šilumos energijos vartojimo mažinimo galimybès. Energetika. 2011. T. 57. Nr. 1. P. 20-25.

37. The Solar Keymark. CEN Keymark Scheme - Sertifikavimo internetinis portalas http://www.estif. org/solarkeymarknew/index.php

38. Perednis E. Plokščiojo saulès kolektoriaus šiluminès ir hidrodinaminès charakteristikos. Energetika. 2004. Nr. 3. P. 60-65.

39. Perednis E., Kavaliauskas A. Saules energijos naudojimo šilumai gaminti Lietuvoje tyrimai. Energetika. 2005. Nr. 4. P. 49-53.

40. Perednis E., Kavaliauskas A., Plikšnienė V. Karšto vandens ruošimo naudojant saulès kolektorius efektyvumo tyrimai. Energetika. 2007. Nr. 1. P. 34-38.

41. Klevas V., Murauskaitè L., Klevienè A., Perednis E. Measures for increasing demand of solar energy. Renewable and Sustainable Energy Reviews. 2013. Vol. 27. P. 55-64.

42. Valančius R., Jurelionis A., Jonynas R., Katinas V., Perednis E. Analysis of medium-scale solar thermal systems and its potential in Lithuania. Energies. 2015. Vol. 8. No. 6. P. 5725-5737.

43. Saules skaičiavimai Raseiniu ir Radviliškio centralizuoto šilumos tiekimo ìmonems. Europos Sąungos programos IEE projekto „SDHplus“ veikloje atliktos galimybiu studijos. Vykdytojas „PlanEnergi“, 2014.

44. Jarmokas R., Katinas V. The possible usage of wind energy in Lithuania. Wind Energy in Baltic International Conference. Riga. 1996.

45. Regional Baltic Wind Energy Programme. Final Report. Prepared by Renewable Energy Laboratory, Lithuanian Energy Institute. Kaunas, 2000.

46. Markevičius A., Katinas V. Vejo energetikos plètros tendencijos. Energetika. 2003. Nr. 1. P. 2-27.

47. Adomavičius V., Linkevičius Ž., Steponavičienè E. Vèjo elektrinès energetinio ir ekonominio efektyvumo priklausomybė nuo bokšto aukščio. Konferencijos „Elektros energetika ir technologijos" pranešimu medžiaga. Kauno technologijos universitetas, 2005. P. 242-247.

48. Neverdauskas E. V., Šulga D. Tolesnès vejjo energetikos skverbties įtaka perdavimo tinklo režimų saugai. Konferencijos „Elektros energetika ir technologijos" pranešimu medžiaga. Kauno technologijos universitetas. 2005. P. 248-251.
49. Katinas V., Markevičius A., Burlakovas A. Vëjo energetika ir jos artimiausia perspektyva Lietuvoje. Energetika. 2006. Nr. 3. P. 67-76.

50. WindPower Development in Baltic States, United Nations Development Programme. www.undp.lt

51. Elektros energijos, kuriai gaminti naudojami atsinaujinantys ir atliekiniai energijos ištekliai, gamybos ir pirkimo skatinimo tvarka. Patvirtinta LR Vyriausybès $2001 \mathrm{~m}$. gruodžio $5 \mathrm{~d}$. nutarimu Nr. 1474 (LR Vyriausybès 2004 m. sausio 13 d. nutarimo Nr. 25 redakcija). 2004 m. sausis.

52. LR ūkio ministro isakymas Nr. 4-102 „Dèl vejjo elektriniu prijungimo prie Lietuvos elektros energetikos sistemos techniniu taisykliu patvirtinimo“. Vilnius, $2004 \mathrm{~m}$. balandis.

53. Markevičius A., Burlakovas A., Tamašauskienè M. Vèjo energetikos plètra iki 2010 metų. Konferencijos „Šilumos energetika ir technologijos" pranešimu medžiaga. Kaunas, 2005 m. vasario $3-4 \mathrm{~d}$.

54. Atsinaujinančius energijos išteklius naudojančiu elektriniu prijungimo prie $330-110 \mathrm{kV}$ elektros perdavimo tinklo iki $2030 \mathrm{~m}$. galimybiu studija. KTU. 2014.

55. Бубялис Э., Макарявичюс В. Процессы энергопереноса в тепловых насосах / ИФТПЭ. Вильнюс: Мокслас, 1990. 186 с. (Теплофизика 22).

56. Aleksandravičius T. A., Klementavičius A., Krakauskas M. Šilumos siurbliu panaudojimo galimybes Lietuvoje. Vilnius: Voruta, 1996. 40 p.

57. Marcinauskas K., Bubelis E. Šilumos siurbliai individualiose sodybose Lietuvoje: prielaidos ir prognozès. Energetika. 2002. Nr. 3. P. 56-66.

58. Вишняускас В.-П. П. Теплообмен и эффективность энергопереноса во внутреннем контуре теплового насоса, работающего по регенеративному ииклу: автореферат дис. на соискание ученой степени кандидата технических наук: 05.14.05. Науч. рук. д.т.н. В. Ю. Макарявичюс. Каунас, 1989. 16 с.

59. Александравичюс Т.-А. П. Разработка узлов двигателя для высокоэфбективной теплонасосной установки Стирлинга: автореферат дис. на соискание ученой степени кандидата технических наук: 05.14.04. Науч. рук. к.т.н. С. С. Нарбутас. Каунас, 1990. 16 с.

60. Нарбутас С. С. Теплообмен и эфбективность энергопереноса в элементах теплонасосной 
установки Стирлинга: автореферат дис. на соискание ученой степени габ. д-ра технических наук: 05.14.05. Каунас, 1991. 75 с.

61. Стасюкинас А.-В. В. Исследование энергопереноса при отборе тепла тепловыми насосами от трансформаторов подстанций: диссертация на соискание ученой степени кандидата технических наук в форме научного доклада: 05.14.04. Каунас, 1992. 33 с.

62. Makarevičius R. Nestacionarių pernešimo procesu regeneracinio šilumos siurblio mainu elementuose tyrimas: daktaro disertacija. Kaunas: KTU, 1997. $134 \mathrm{p}$.

63. Marcinauskas K, Bubelis E. Kėdainių m. centralizuoto šilumos tiekimo pertvarkymo galimybès ir jo techninis ivertinimas. Energetika. 1995. Nr. 4. P. 41-48.

64. Marcinauskas K. Atliekiniai energijos ištekliai - pirminių energijos išteklių taupymo rezervas (1991-2002 m. atliktų tiriamųjų darbų apžvalga). Energetika. 2003. Nr. 1. P. 11-21.

65. Jablonskis J., Jurgelènaitė A., Tomkevičienė A. Lietuvos upių šilumos ištekliai ir jų daugiamete kaita. Energetika. 2013. T. 59. Nr. 4. P. 203-210.

66. Gaigalis V., Skema R., Marcinauskas K., Korsakiene I. A review on heat pumps implementation in Lithuania on compliance with the National Energy Strategy and EU policy. Renewable and Sustainable Energy Reviews. 2016. Vol. 53. P. 841-858.

67. Nacionaline energijos vartojimo didinimo 2006$2010 \mathrm{~m}$. programa. Patvirtinta LR Vyriausybès 2006 m. gegužès 11 d. nutarimu Nr. 443 (Žin., 2006, Nr. 54-1956).

68. Lietuvos hidroenergetika - 15 metu veikla 19962011. Lietuvos hidroenergetikų asociacijos leidinys, 2012.

69. Jablonskis J., Lasinskas M. Lietuvos TSR upių kadastras, III dalis (Debitai, nuolydžiai, galingumas). Vilnius: LTSR MA Energetikos ir elektrotechnikos institutas, 1962. 638 p.; J. Jablonskis. Lietuvos TSR upiu kadastras, III dalies VI priedas (Kadastriniai grafikai). Vilnius, 1962. 191 p.
70. Žaliosios energetikos centras. http://www.zec.lt/ energetikos-rusys/hidro-energija

71. Punys P., Ruplys B. Šalies hidroenergetika: išblèsusios perspektyvos. Energijos erdvé. 2011. Nr. 3(10). P. 4-11.

72. Jablonskis J., Jurgelènaitė A., Tomkevičienè A. Hidroenergetika aplinkos apsaugos kontekste. Energetika. 2007. T. 53. Nr. 3. P. 48-56.

73. Juknys R. ir kt. Antropogeninių aplinkos pokyčiu ir klimato poveikis ekosistemoms. VDU mokslo klasteriai, 3 dalis. 2010.

\section{Mantas Marčiukaitis,}

Eugenija Farida Dzenajavičienė, Vaclovas Kveselis, Juozas Savickas, Eugenijus Perednis,

Aurimas Lisauskas, Antanas Markevičius,

Kazys Marcinauskas, Giedrius Gecevičius,

Regina Erlickytè-Marčiukaitienè

\section{EXPERIENCE, IMPLICATIONS AND}

\section{PROSPECTS OF THE USE OF RENEWABLE} ENERGY SOURCES IN LITHUANIA

\section{Summary}

Renewable energy sources, their efficient use and development are among the strategic goals of sustainable national energy strategy, and implementation of these goals reduces dependence on fossil fuel import, increases security of heat supply and reduces emissions of greenhouse gases into the atmosphere. The use of the above-mentioned resources can also reduce energy generation, improve the quality of the living environment, create jobs with simultaneous improvement of employment and reduction of social exclusion in the regions. The article provides an overview of the use of all renewable energy in Lithuania, including current status, sustainability aspects - economic, environmental and social - as well as discussion of future development trends and prospective.

Keywords: renewable energy sources, climate change prevention, security of heat supply, economic and social benefit 